\title{
Diagnosis and Treatment of Diabetic Foot Infections
}

\author{
Benjamin A. Lipsky, ${ }^{\text {,a }}$ Anthony R. Berendt, ${ }^{2, a}$ H. Gunner Deery, ${ }^{3}$ John M. Embil, ${ }^{4}$ Warren S. Joseph, ${ }^{5}$ \\ Adolf W. Karchmer, ${ }^{6}$ Jack L. LeFrock, ${ }^{7}$ Daniel P. Lew, ${ }^{8}$ Jon T. Mader, ${ }^{9, b}$ Carl Norden, ${ }^{10}$ and James S. Tan ${ }^{11}$ \\ ${ }^{1}$ Medical Service, Veterans Affairs Puget Sound Health Care System, and Division of General Internal Medicine, Department of Medicine, \\ University of Washington School of Medicine, Seattle, Washington; ${ }^{2}$ Bone Infection Unit, Nuffield Orthopaedic Centre, Oxford, United Kingdom; \\ ${ }^{3}$ Northern Michigan Infectious Diseases, Petoskey, Michigan; ${ }^{4}$ Section of Infectious Diseases, Department of Medicine, University of Manitoba, \\ Winnipeg, Manitoba; ${ }^{5}$ Section of Podiatry, Department of Primary Care, Veterans Affairs Medical Center, Coatesville, Pennsylvania; ${ }^{6}$ Division \\ of Infectious Diseases, Department of Medicine, Harvard Medical School, and Beth Israel Deaconess Medical Center, Boston, Massachusetts; \\ ${ }^{7}$ Dimensional Dosing Systems, Sarasota, Florida; ${ }^{8}$ Department of Medicine, Service of Infectious Diseases, University of Geneva Hospitals, \\ Geneva, Switzerland; ${ }^{\circ}$ Department of Internal Medicine, The Marine Biomedical Institute, and Department of Orthopaedics and Rehabilitation, \\ University of Texas Medical Branch, Galveston, Texas; ${ }^{10}$ Department of Medicine, New Jersey School of Medicine and Dentistry, and Cooper \\ Hospital, Camden, New Jersey; and "Department of Internal Medicine, Summa Health System, and Northeastern Ohio Universities \\ College of Medicine, Akron, Ohio
}

\section{EXECUTIVE SUMMARY}

1. Foot infections in patients with diabetes cause substantial morbidity and frequent visits to health care professionals and may lead to amputation of a lower extremity.

2. Diabetic foot infections require attention to local (foot) and systemic (metabolic) issues and coordinated management, preferably by a multidisciplinary footcare team (A-II) (table 1). The team managing these infections should include, or have ready access to, an infectious diseases specialist or a medical microbiologist (B-II).

3. The major predisposing factor to these infections is foot ulceration, which is usually related to peripheral neuropathy. Peripheral vascular disease and various immunological disturbances play a secondary role.

4. Aerobic gram-positive cocci (especially Staphylococcus aureus) are the predominant pathogens in diabetic foot infections. Patients who have chronic

Received 2 July 2004; accepted 2 July 2004; electronically published 10 September 2004.

These guidelines were developed and issued on behalf of the Infectious Diseases Society of America.

a B.A.L. served as the chairman and A.R.B. served as the vice chairman of the Infectious Diseases Society of America Guidelines Committee on Diabetic Foot Infections.

${ }^{b}$ Deceased.

Reprints or correspondence: Dr. Benjamin A. Lipsky, Veterans Affairs Puget Sound Health Care System, S-111-GIMC, 1660 S. Columbian Way, Seattle, WA 981089804 (Benjamin.Lipsky@med.va.gov).

Clinical Infectious Diseases 2004; 39:885-910

This article is in the public domain, and no copyright is claimed 1058-4838/2004/3907-0001 wounds or who have recently received antibiotic therapy may also be infected with gram-negative rods, and those with foot ischemia or gangrene may have obligate anaerobic pathogens.

5. Wound infections must be diagnosed clinically on the basis of local (and occasionally systemic) signs and symptoms of inflammation. Laboratory (including microbiological) investigations are of limited use for diagnosing infection, except in cases of osteomyelitis (B-II).

6. Send appropriately obtained specimens for culture prior to starting empirical antibiotic therapy in all cases of infection, except perhaps those that are mild and previously untreated (B-III). Tissue specimens obtained by biopsy, ulcer curettage, or aspiration are preferable to wound swab specimens (A-I).

7. Imaging studies may help diagnose or better define deep, soft-tissue purulent collections and are usually needed to detect pathological findings in bone. Plain radiography may be adequate in many cases, but MRI (in preference to isotope scanning) is more sensitive and specific, especially for detection of soft-tissue lesions (A-I).

8. Infections should be categorized by their severity on the basis of readily assessable clinical and laboratory features (B-II). Most important among these are the specific tissues involved, the adequacy of arterial perfusion, and the presence of systemic toxicity or metabolic instability. Categorization helps determine the degree of risk to the patient and the limb and, thus, the urgency and venue of management.

9. Available evidence does not support treat- 

Table 1. Infectious Diseases Society of America-United States Public Health Service Grading System for ranking rec-
ommendations in clinical guidelines.

\begin{tabular}{ll}
\hline Category, grade & Definition \\
\hline Strength of recommendation & \\
A & Good evidence to support a recommendation for use; should always be offered \\
B & Moderate evidence to support a recommendation for use; should generally be offered \\
C & Poor evidence to support a recommendation; optional \\
D & Moderate evidence to support a recommendation against use; should generally not be offered \\
E & Good evidence to support a recommendation against use; should never be offered \\
Quality of evidence & Evidence from $\geqslant 1$ properly randomized, controlled trial \\
I & Evidence from $\geqslant 1$ well-designed clinical trial, without randomization; from cohort or case- \\
& controlled analytic studies (preferably from $>1$ center); from multiple time-series; or from \\
dII & dramatic results from uncontrolled experiments \\
& Evidence from opinions of respected authorities, based on clinical experience, descriptive \\
\hline
\end{tabular}

ing clinically uninfected ulcers with antibiotic therapy (D-III). Antibiotic therapy is necessary for virtually all infected wounds, but it is often insufficient without appropriate wound care.

10. Select an empirical antibiotic regimen on the basis of the severity of the infection and the likely etiologic agent(s) (B-II). Therapy aimed solely at aerobic gram-positive cocci may be sufficient for mild-to-moderate infections in patients who have not recently received antibiotic therapy (A-II). Broadspectrum empirical therapy is not routinely required but is indicated for severe infections, pending culture results and antibiotic susceptibility data (B-III). Take into consideration any recent antibiotic therapy and local antibiotic susceptibility data, especially the prevalence of methicillin-resistant $S$. aureus (MRSA) or other resistant organisms. Definitive therapy should be based on both the culture results and susceptibility data and the clinical response to the empirical regimen (C-III).

11. There is only limited evidence with which to make informed choices among the various topical, oral, and parenteral antibiotic agents. Virtually all severe and some moderate infections require parenteral therapy, at least initially (C-III). Highly bioavailable oral antibiotics can be used in most mild and in many moderate infections, including some cases of osteomyelitis (A-II). Topical therapy may be used for some mild superficial infections (B-I).

12. Continue antibiotic therapy until there is evidence that the infection has resolved but not necessarily until a wound has healed. Suggestions for the duration of antibiotic therapy are as follows: for mild infections, 1-2 weeks usually suffices, but some require an additional 1-2 weeks; for moderate and severe infections, usually $2-4$ weeks is sufficient, depending on the structures involved, the adequacy of debridement, the type of soft-tissue wound cover, and wound vascularity (A-II); and for osteomyelitis, generally at least 4-6 weeks is required, but a shorter duration is sufficient if the entire infected bone is removed, and probably a longer duration is needed if infected bone remains (B-II).

13. If an infection in a clinically stable patient fails to respond to $\geqslant 1$ antibiotic courses, consider discontinuing all antimicrobials and, after a few days, obtaining optimal culture specimens (C-III).

14. Seek surgical consultation and, when needed, intervention for infections accompanied by a deep abscess, extensive bone or joint involvement, crepitus, substantial necrosis or gangrene, or necrotizing fasciitis (A-II). Evaluating the limb's arterial supply and revascularizing when indicated are particularly important. Surgeons with experience and interest in the field should be recruited by the foot-care team, if possible.

15. Providing optimal wound care, in addition to appropriate antibiotic treatment of the infection, is crucial for healing (A-I). This includes proper wound cleansing, debridement of any callus and necrotic tissue, and, especially, off-loading of pressure. There is insufficient evidence to recommend use of a specific wound dressing or any type of wound healing agents or products for infected foot wounds.

16. Patients with infected wounds require early and careful follow-up observation to ensure that the selected medical and surgical treatment regimens have been appropriate and effective (B-III).

17. Studies have not adequately defined the role of most adjunctive therapies for diabetic foot infections, but systematic reviews suggest that granulocyte colony-stimulating factors and systemic hyperbaric oxygen therapy may help prevent amputations (B-I). These treatments may be useful for severe infections or for those that have not adequately responded to therapy, despite correcting for all amenable local and systemic adverse factors.

18. Spread of infection to bone (osteitis or osteomyelitis) may be difficult to distinguish from noninfectious osteoar- 
thropathy. Clinical examination and imaging tests may suffice, but bone biopsy is valuable for establishing the diagnosis of osteomyelitis, for defining the pathogenic organism(s), and for determining the antibiotic susceptibilities of such organisms (B-II).

19. Although this field has matured, further research is much needed. The committee especially recommends that adequately powered prospective studies be undertaken to elucidate and validate systems for classifying infection, diagnosing osteomyelitis, defining optimal antibiotic regimens in various situations, and clarifying the role of surgery in treating osteomyelitis (A-III).

\section{INTRODUCTION}

Purpose of the guideline. Foot infections in persons with diabetes are a common, complex, and costly problem [1-4]. In addition to causing severe morbidities, they now account for the largest number of diabetes-related hospital bed-days [5] and are the most common proximate, nontraumatic cause of amputations $[6,7]$. Diabetic foot infections require careful attention and coordinated management, preferably by a multidisciplinary foot-care team (A-II) [8-13]. The team managing these infections should preferably include, or have ready access to, an infectious diseases specialist or a medical microbiologist (B-III) [1]. Optimal management of diabetic foot infections can potentially reduce the incidence of infection-related morbidities, the need for and duration of hospitalization, and the incidence of major limb amputation [14, 15]. Unfortunately, these infections are frequently inadequately managed [16]. This may result from a lack of understanding of current diagnostic and therapeutic approaches, insufficient resources devoted to the problem, or a lack of effective multidisciplinary collaboration. The primary purpose of this guideline is to help reduce the medical morbidity, psychological distress, and financial costs associated with diabetic foot infections.

The focus of this guideline is primarily on managing the diabetic patient with suspected or evident foot infection, because other published guidelines cover the general management of the diabetic foot and diabetic foot ulceration [17-19]. The committee members realize that the realities of primary care practice and the scarcity of resources in some clinical situations will restrict the implementation of some of the recommended procedures and treatments. We believe, however, that in almost all settings, high-quality care is usually no more difficult to achieve or expensive than poor care and its consequences [20, 21].

This guideline should provide a framework for treating all diabetic patients who have a suspected foot infection. Some health care centers will be able to implement it immediately, whereas others will need increased resources, better staff training, and intensified coordination of available expertise. Use of this guideline may reduce the burdens (medical, financial, and ecological) associated with inappropriate practices, including those related to antibiotic prescribing, wound care, hospitalization decisions, diagnostic testing, surgical procedures, and adjunctive treatments. We hope it will contribute to reducing the rates of lower extremity amputation, in line with the international St. Vincent declaration [22]. Cost savings may en-

Table 2. Risk factors for foot ulceration and infection.

\begin{tabular}{|c|c|}
\hline Risk factor & Mechanism of injury or impairment \\
\hline Peripheral motor neuropathy & $\begin{array}{l}\text { Abnormal foot anatomy and biomechanics, with clawing of } \\
\text { toes, high arch, and subluxed metatarsophalangeal joints, } \\
\text { leading to excess pressure, callus formation, and ulcers }\end{array}$ \\
\hline Peripheral sensory neuropathy & $\begin{array}{l}\text { Lack of protective sensation, leading to unattended minor } \\
\text { injuries caused by excess pressure or mechanical or ther- } \\
\text { mal injury }\end{array}$ \\
\hline Peripheral autonomic neuropathy & Deficient sweating leading to dry, cracking skin \\
\hline $\begin{array}{l}\text { Neuro-osteoarthropathic deformities (i.e., Charcot disease) } \\
\text { or limited joint mobility }\end{array}$ & $\begin{array}{l}\text { Abnormal anatomy and biomechanics, leading to excess } \\
\text { pressure, especially in the midplantar area }\end{array}$ \\
\hline Vascular (arterial) insufficiency & $\begin{array}{l}\text { Impaired tissue viability, wound healing, and delivery of } \\
\text { neutrophils }\end{array}$ \\
\hline Hyperglycemia and other metabolic derangements & $\begin{array}{l}\text { Impaired immunological (especially neutrophil) function and } \\
\text { wound healing and excess collagen cross-linking }\end{array}$ \\
\hline Patient disabilities & Reduced vision, limited mobility, and previous amputation(s) \\
\hline Maladaptive patient behaviors & $\begin{array}{l}\text { Inadequate adherence to precautionary measures and foot } \\
\text { inspection and hygiene procedures, poor compliance with } \\
\text { medical care, inappropriate activities, excessive weight- } \\
\text { bearing, and poor footwear }\end{array}$ \\
\hline Health care system failures & $\begin{array}{l}\text { Inadequate patient education and monitoring of glycemic } \\
\text { control and foot care }\end{array}$ \\
\hline
\end{tabular}


Table 3. Pathogens associated with various clinical foot-infection syndromes.

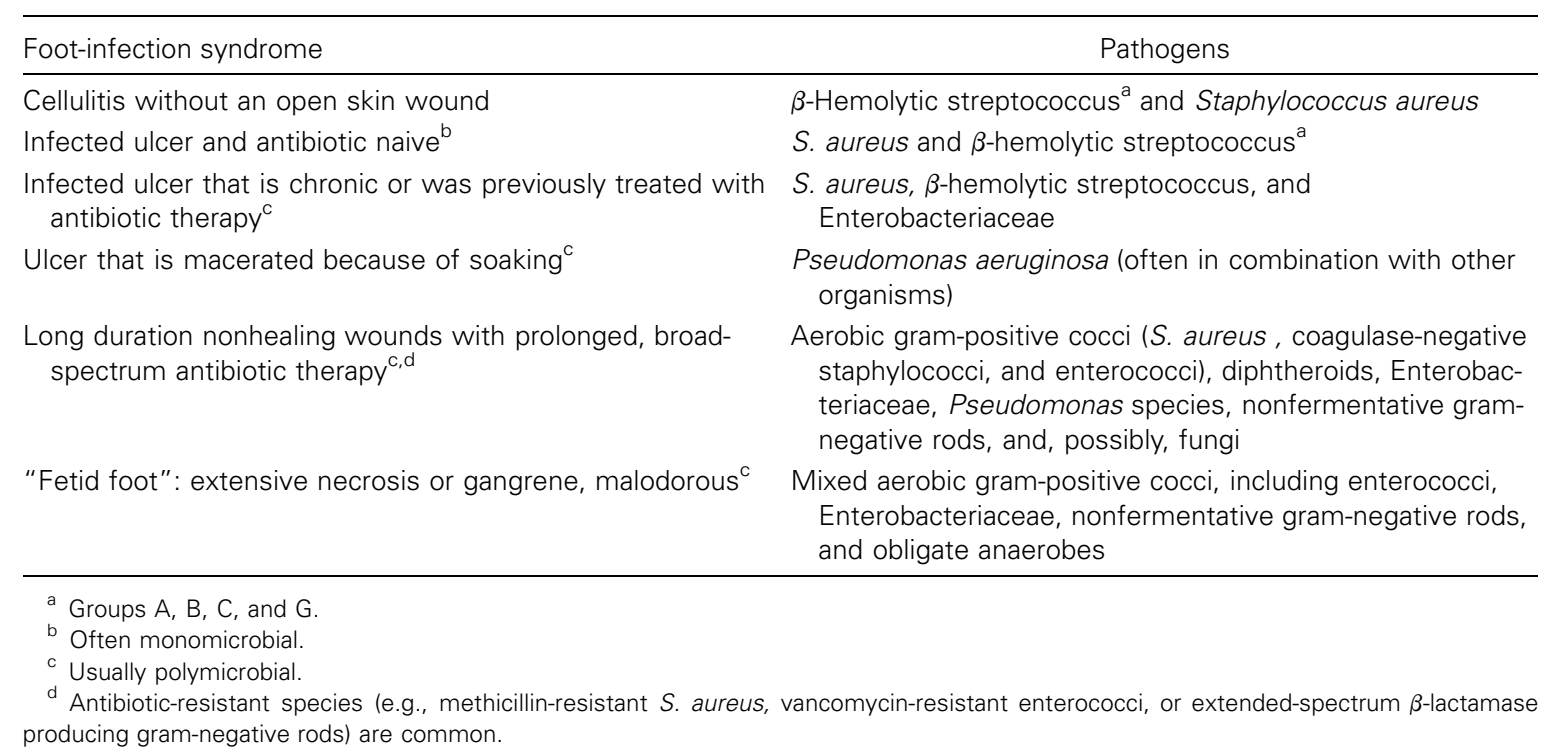

sue, although this may be offset by an increased demand for preventive foot care, diagnostic testing (especially MRI), and vascular interventions [12].

Methodology. This guideline committee is comprised of Infectious Diseases Society of America members with experience and interest in diabetic foot infections, many of whom also have experience in writing guidelines. Committee members are from several US states and other countries; their backgrounds represent academia, bench and clinical research, infectious diseases clinical practice, podiatry, and industry. Three of the members are also members of the International Working Group on the Diabetic Foot, which published its International Consensus Guidelines on Diagnosing and Treating Diabetic Foot Infections in 2003 [23]. After an extensive literature search (which included the MEDLINE database, the EBSCO database, the Cochrane Library, diabetic foot Web sites and bibliographies, and hand-searching of bibliographies of published articles), committee members reviewed and discussed all available evidence in a series of meetings and established consensus through discussion and debate over a period of 3 years. Three subcommittees drafted subsections that were modified and exchanged; these served as a basis for the final document, which underwent numerous revisions that were based on both internal and external reviews. Because of the relative paucity of randomized controlled trials or other high-quality evidence in this field, most of our recommendations are based on discussion and consensus (B-II) (table 1) [24]. Thus, we elected to offer a relatively brief summary and to provide an extensive bibliography for those who would like to review the data themselves.

\section{PATHOPHYSIOLOGY OF INFECTION}

A diabetic foot infection is most simply defined as any inframalleolar infection in a person with diabetes mellitus. These include paronychia, cellulitis, myositis, abscesses, necrotizing fasciitis, septic arthritis, tendonitis, and osteomyelitis. The most common and classical lesion, however, is the infected diabetic "mal perforans" foot ulcer. This wound results from a complex amalgam of risk factors $[25,26]$, which are summarized in table 2. Neuropathy plays the central role, with disturbances of sensory, motor, and autonomic functions leading to ulceration due to trauma or excessive pressure on a deformed foot that lacks protective sensation. Once the protective layer of skin is breached, underlying tissues are exposed to bacterial colonization. This wound may progress to become actively infected, and, by contiguous extension, the infection can involve deeper tissues. This sequence of events can be rapid (occurring over days or even hours), especially in an ischemic limb. Various poorly characterized immunologic disturbances, especially those that involve polymorphonuclear leukocytes, may affect some diabetic patients, and these likely increase the risk and severity of foot infections [27-30].

\section{MICROBIOLOGY}

Aerobic gram-positive cocci are the predominant microorganisms that colonize and acutely infect breaks in the skin. S. aureus and the $\beta$-hemolytic streptococci (groups A, C, and G, but especially group $\mathrm{B}$ ) are the most commonly isolated pathogens [31-38]. Chronic wounds develop a more complex colonizing flora, including enterococci, various Enterobacteriaceae, obligate anaerobes, Pseudomonas aeruginosa, and, sometimes, other nonfermentative gram-negative rods [39-43]. Hospitalization, surgical procedures, and, especially, prolonged or broad-spectrum antibiotic therapy may predispose patients to colonization and/or infection with antibiotic-resistant organisms (e.g., MRSA or vancomycin-resistant enterococci [VRE]) [44]. Al- 


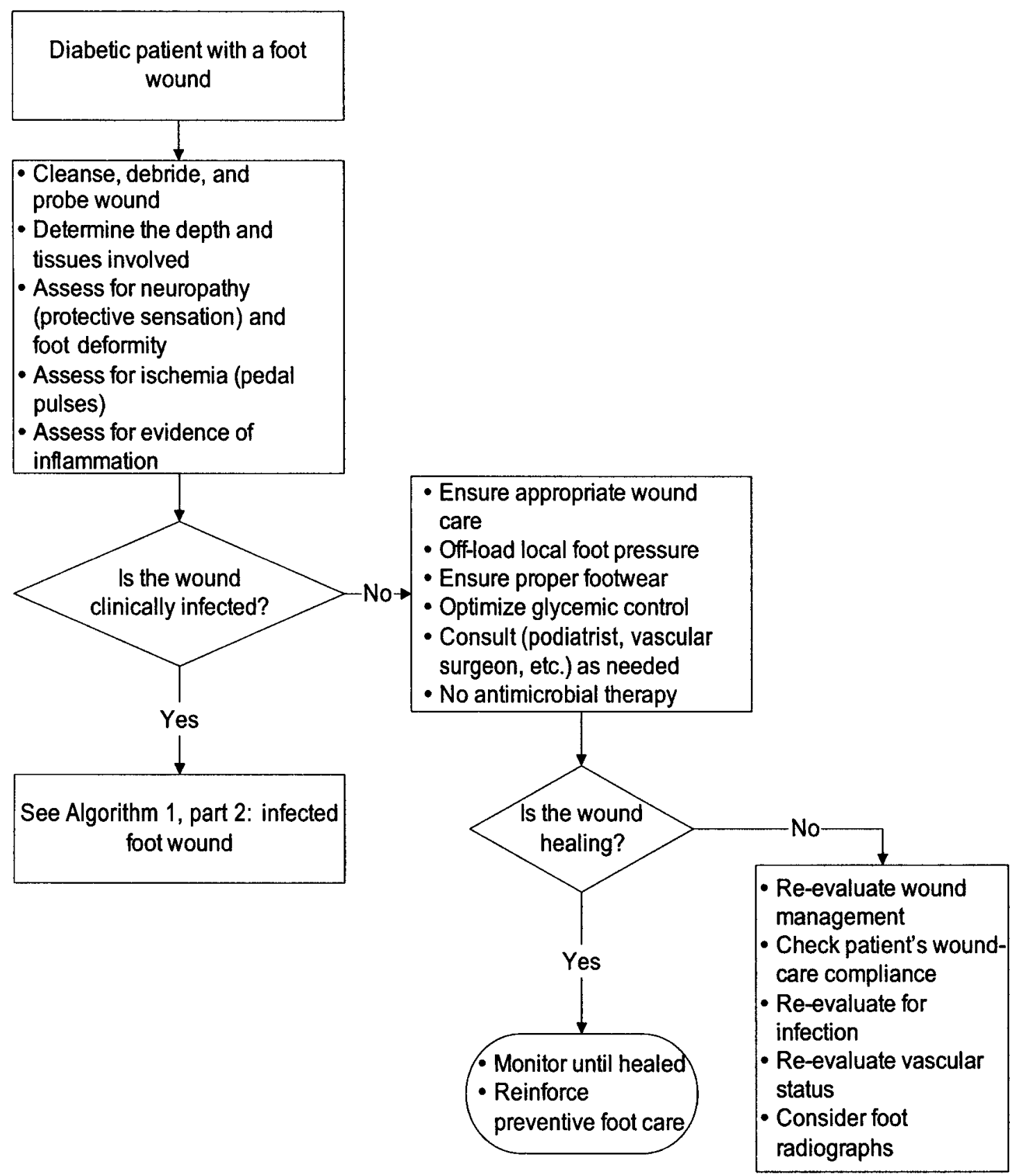

Figure 1. Algorithm 1, part 1: approach to treating a diabetic patient with a foot wound

though MRSA strains have previously been isolated mainly from hospitalized patients, community-associated cases are now becoming common [45] and are associated with worse outcomes in patients with diabetic foot infections [46-48]. Vancomycin (or glycopeptide)-intermediate $S$. aureus has been isolated in several countries. Of note, the first 2 reported cases of vancomycin-resistant $S$. aureus each involved a diabetic patient with a foot infection [49].

The impaired host defenses around necrotic soft tissue or bone may allow low-virulence colonizers, such as coagulase- negative staphylococci and Corynebacterium species ("diphtheroids"), to assume a pathogenic role $[43,50]$. Acute infections in patients who have not recently received antimicrobials are often monomicrobial (almost always with an aerobic grampositive coccus), whereas chronic infections are often polymicrobial [31, 36, 43, 51]. Cultures of specimens obtained from patients with such mixed infections generally yield 3-5 isolates, including gram-positive and gram-negative aerobes and anaerobes $[14,34,37,38,40,41,52-58]$. The pathogenic role of each isolate in a polymicrobial infection is often unclear. Table 


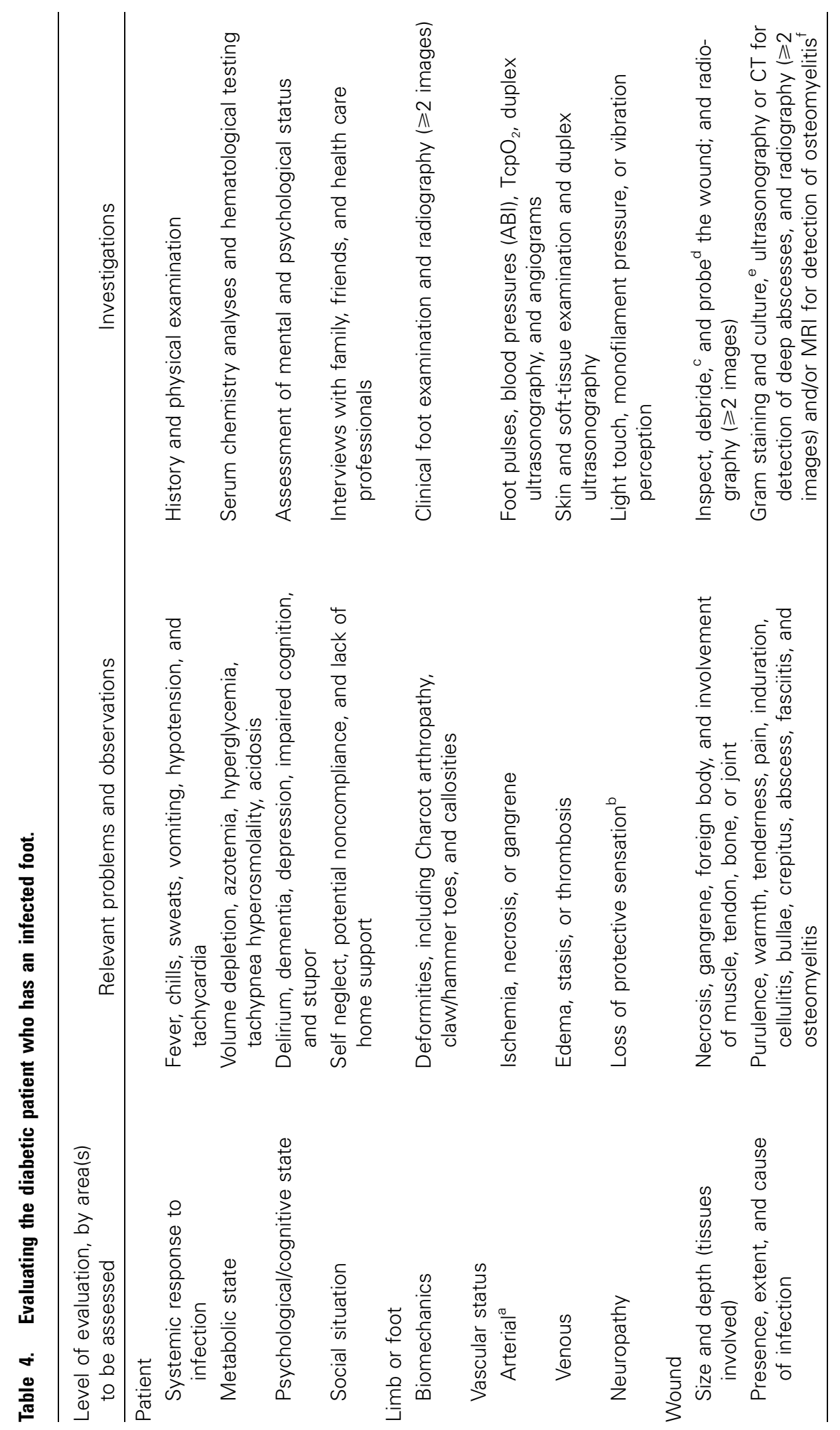




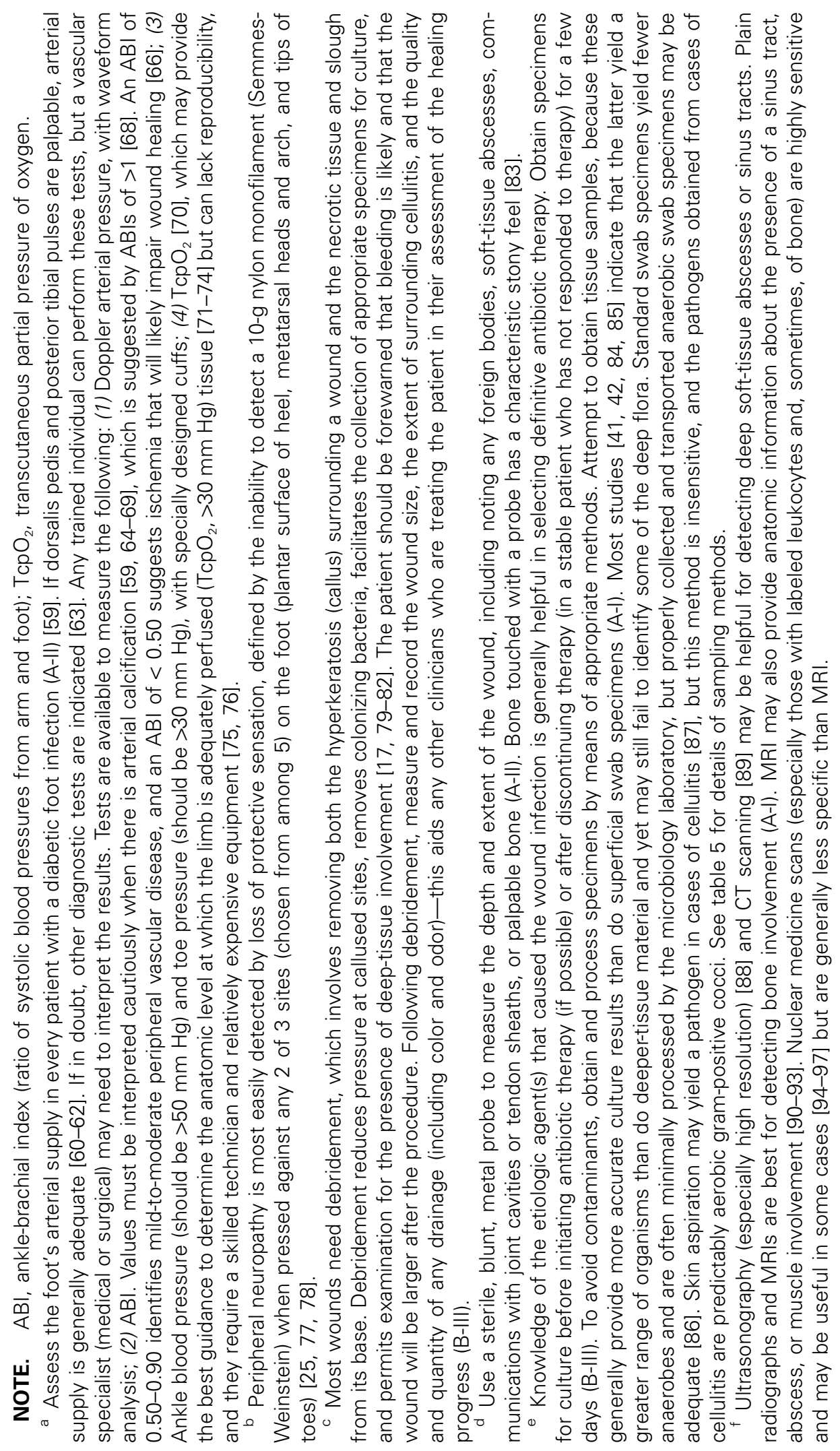


3 lists common clinical infection syndromes and the pathogens most likely isolated in conjunction with them.

\section{EVALUATING THE PATIENT, THE WOUND, AND THE INFECTION}

Diabetic patients may develop many types of foot wounds, any of which can become infected. Infection should be diagnosed clinically on the basis of the presence of purulent secretions (pus) or at least 2 of the cardinal manifestations of inflammation (redness, warmth, swelling or induration, and pain or tenderness); not all ulcers are infected (figure 1) (B-II) [23]. Curing an infection often contributes to, but is not defined by, healing of an ulcer. Management of diabetic foot infections involves evaluating and determining the severity of infection as the basis for selecting the appropriate approach to treatment $[15,23,40]$ (B-II). The issue of osteomyelitis is particularly complex and problematic and is thus dealt with separately.

Evaluation of the infection should occur at 3 levels, as outlined in tables 4 and 5 (B-III): the patient as a whole, the affected limb or foot, and the infected wound. The goal is to determine the clinical extent (table 4) and the microbial etiology (table 5) of the infection, the biology or pathogenesis of the wound, any contribution of altered foot biomechanics to the cause of the wound (and, thus, its ability to heal), any contribution of vascular (especially arterial) disease, and the presence of any systemic consequences of infection. Clinicians lacking the skills or experience to conduct any of these assessments should seek appropriate consultation.

\section{DETERMINING THE SEVERITY OF INFECTION}

The results of the evaluations described in table 4 can be used to determine the overall severity of the infection and to formulate a management plan (figure 2) (B-II). Unfortunately, the lack of consensus on wound definitions and infection classification systems hampers comparison of published studies. The
Wagner system [15, 40, 98, 99] has been widely used for 25 years but was developed for the "dysvascular" foot, is skewed toward severe disease, and contains all infections within a single grade [100-105]. Consensus is developing that the key issues in classifying a diabetic foot wound are its depth (in particular, which tissues are involved) and whether the wound is complicated by either ischemia or infection [23, 101, 106-108] (BII). The International Consensus on the Diabetic Foot recently published a preliminary progress report on a diabetic foot ulcer classification system for research purposes [23]. The key elements are summarized by the acronym PEDIS (perfusion, extent/size, depth/tissue loss, infection, and sensation). The infection category includes grades 1 (no infection), 2 (involvement of skin and subcutaneous tissue only), 3 (extensive cellulitis or deeper infection), and 4 (presence of a systemic inflammatory response syndrome). Because this research-based system is designed to be applicable to all ulcers, it includes a category of grade 1 for uninfected lesions; grades $2-4$ are similar to those we describe in table 6.

For infected wounds (figure 2), the most important initial task is to recognize patients who require immediate hospitalization, parenteral and broad-spectrum empirical antibiotic therapy, and urgent consideration of diagnostic testing and surgical consultation. We have defined these potentially lifethreatening infections as "severe." Infections defined as "mild" must be distinguished from clinically uninfected lesions but are otherwise relatively easy to recognize. Defining infections as "moderate" poses the greatest difficulty, because this term covers a broad spectrum of wounds, some of which can be quite complicated and even limb threatening. Other classification schemes have used the terms "uncomplicated" and "complicated" synonymously with mild and moderate, but we wish to avoid confusion with the various complications that can beset a wound. The distinction between moderate and severe infections has less to do with the status of the foot than

Table 5. Collection of soft-tissue specimens from an infected diabetic foot for culture.

When

- Culturing clinically uninfected lesions is unnecessary, unless done as part of an infection-control surveillance protocol (C-III).

- Cultures of infected wounds are valuable for directing antibiotic choices, but may be unnecessary in cases of acute mild infection in an antibiotic-naive patient (B-III).

- Blood cultures should be performed for a patient with a severe infection, especially if the patient is systemically ill (C-III).

How

- Cleanse and debride the lesion before obtaining specimens for culture.

- In cases involving an open wound, obtain tissue specimens from the debrided base (whenever possible) by means of curettage (scraping with a sterile dermal curette or scalpel blade) or biopsy (bedside or operative) (A-I).

- Avoid swabbing undebrided ulcers or wound drainage. If swabbing the debrided wound base is the only available culture option, use a swab designed for culturing aerobic and anaerobic organisms and rapidly transport it to the laboratory (B-I).

- Needle aspiration may be useful for obtaining purulent collections or, perhaps, a specimen from an area of cellulitis.

- Clearly identify samples (specimen type and anatomic location), and promptly send them to the laboratory in an appropriate sterile container or transport media for aerobic and anaerobic culture. 


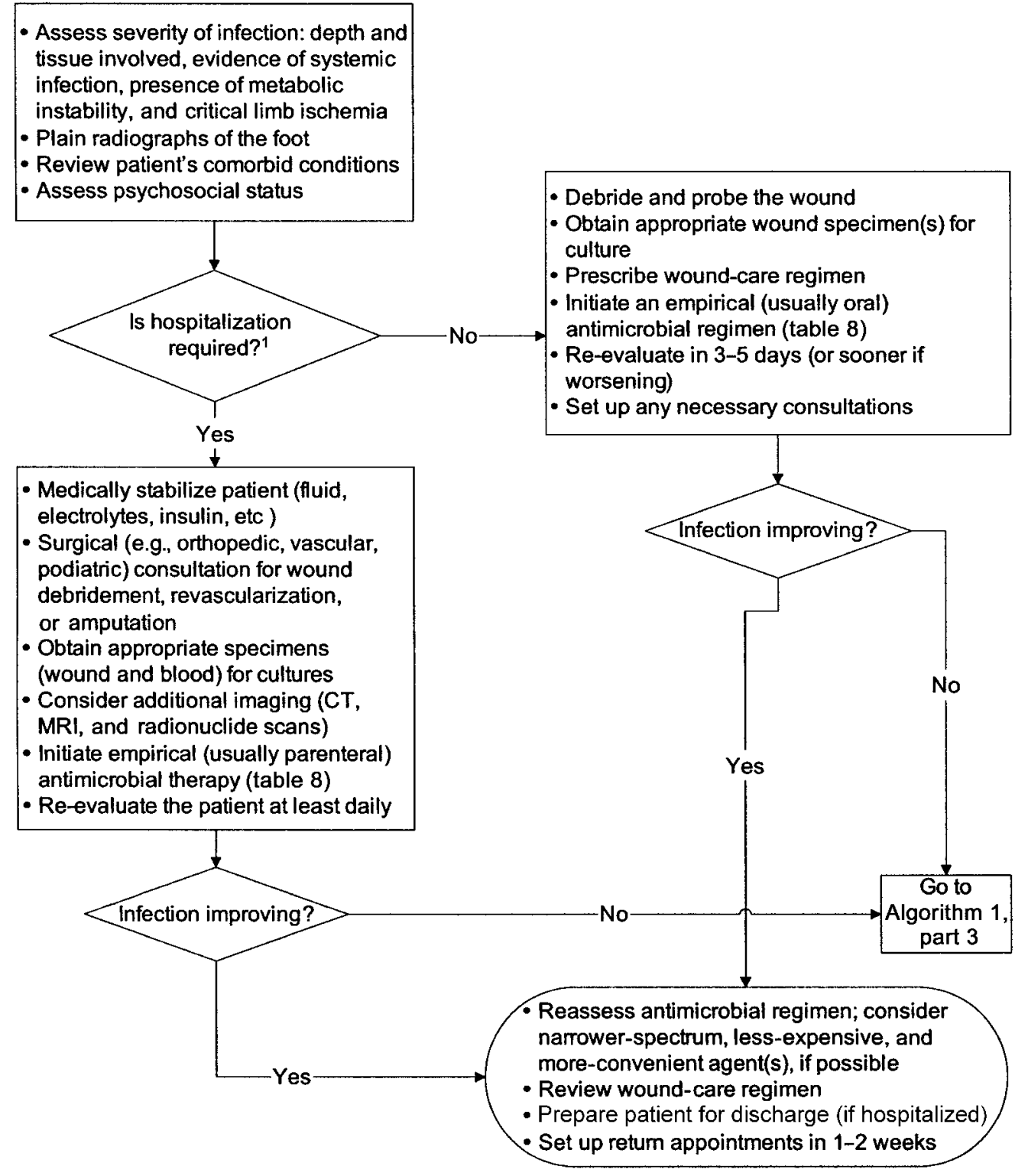

Figure 2. Algorithm 1, part 2: approach to treating a diabetic patient with a foot infection. ${ }^{1}$ Consider hospitalization if any of the following criteria are present: systemic toxicity (e.g., fever and leukocytosis); metabolic instability (e.g., severe hypoglycemia or acidosis); rapidly progressive or deeptissue infection, substantial necrosis or gangrene, or presence of critical ischemia; requirement of urgent diagnostic or therapeutic interventions; and inability to care for self or inadequate home support.

with the patient to whom it is attached. This distinction is complicated by the fact that $\geqslant 50 \%$ of patients with a limbthreatening infection do not manifest systemic signs or symptoms. After debating several classification schemes, we propose the one presented in table 6 as a basis for subsequent discussions in and beyond this guideline (B-II).

\section{TREATMENT OF INFECTION}

Avoid prescribing antibiotics for uninfected ulcerations. Some argue that many apparently uninfected diabetic foot ulcers are actually subclinically infected-that is, they contain a high "bioburden" of bacteria (usually defined as $>10^{5}$ organisms per gram of tissue) that results in "critical colonization" levels and impairs wound healing [54, 109-114]. Available published evidence does not support the use of antibiotics for the management of clinically uninfected ulcerations, either to enhance wound healing or as prophylaxis against infection $[115,116]$. Because antibiotic use encourages antimicrobial resistance, incurs financial cost, and may cause drug-related adverse effects, we discourage therapy of uninfected ulcers. In some circumstances, it is difficult to decide whether a chronic wound is infected, such as when the foot is ischemic, has abnormal col- 
Table 6. Clinical classification of a diabetic foot infection.

\begin{tabular}{|c|c|c|}
\hline Clinical manifestations of infection & $\begin{array}{l}\text { Infection } \\
\text { severity }\end{array}$ & $\begin{array}{l}\text { PEDIS } \\
\text { grade }^{a}\end{array}$ \\
\hline Wound lacking purulence or any manifestations of inflammation & Uninfected & 1 \\
\hline $\begin{array}{l}\text { Presence of } \geqslant 2 \text { manifestations of inflammation (purulence, or erythema, pain, } \\
\text { tenderness, warmth, or induration), but any cellulitis/erythema extends } \leqslant 2 \\
\mathrm{~cm} \text { around the ulcer, and infection is limited to the skin or superficial subcu- } \\
\text { taneous tissues; no other local complications or systemic illness. }\end{array}$ & Mild & 2 \\
\hline $\begin{array}{l}\text { Infection (as above) in a patient who is systemically well and metabolically sta- } \\
\text { ble but which has } \geqslant 1 \text { of the following characteristics: cellulitis extending }>2 \\
\text { cm, lymphangitic streaking, spread beneath the superficial fascia, deep-tissue } \\
\text { abscess, gangrene, and involvement of muscle, tendon, joint or bone }\end{array}$ & Moderate & 3 \\
\hline $\begin{array}{l}\text { Infection in a patient with systemic toxicity or metabolic instability (e.g., fever, } \\
\text { chills, tachycardia, hypotension, confusion, vomiting, leukocytosis, acidosis, } \\
\text { severe hyperglycemia, or azotemia) }\end{array}$ & Severe & 4 \\
\hline
\end{tabular}

oration or a fetid odor, has friable granulation tissue, is associated with unexpected pain or tenderness, or when an otherwise properly treated ulcer fails to show healing progress [117, 118]. In these unusual cases, a brief, culture-directed course of antibiotic therapy may be appropriate (C-III).

Determine the need for hospitalization. Hospitalization is the most expensive part of treating a diabetic foot infection, and deciding on its necessity requires consideration of both medical and social issues. Patients with infections that are either severe or complicated by critical limb ischemia should generally be hospitalized (C-III) $[119,120]$. Some patients with apparently mild infections and more patients with moderate infections may also need hospitalization; this may be for observation, urgent diagnostic testing, or because complicating factors are likely to affect their wound care or adherence to antibiotic treatment. In the absence of these complicating features, most patients with mild or moderate infections can be treated as outpatients (A-II) [84, 121].

Stabilize the patient. Attending to the general metabolic state of the patient is essential [25, 122]. This may involve restoration of the fluid and electrolyte balances; correction of hyperglycemia, hyperosmolality, acidosis, and azotemia; and treatment of other exacerbating disorders. Critically ill patients who require surgery should usually be stabilized before transfer to the operating room, although surgery should usually not be delayed for $>48 \mathrm{~h}$ after presentation to the hospital (B-III) [123]. The improvement of glycemic control may aid in both eradicating the infection and healing the wound [124]. As the infection improves, hyperglycemia may be easier to control.

Choose an antibiotic regimen. Selection of the antibiotic regimen initially involves decisions about the route of therapy, the spectrum of microorganisms to be covered, and the specific drugs to administer and later involves choosing the definitive regimen and the duration of treatment. Initial therapy is usually empirical and should be based on the severity of the infection and on any available microbiological data, such as recent culture results or current Gram-stained smear findings. For severe infections and for more-extensive, chronic moderate infections, it is safest to commence therapy with broad-spectrum agents. These should have activity against gram-positive cocci (including MRSA in locations where this pathogen is common), as well as gram-negative and obligate anaerobic organisms (B-III). To ensure adequate and prompt tissue concentrations, therapy should be given parenterally, at least initially (C-III). Although some suggest broad-spectrum empirical therapy for most infections [125-127], the majority of mild-and many moderate-infections can be treated with agents with a relatively narrow spectrum, such as those covering only aerobic grampositive cocci (A-II) [84]. Although anaerobic organisms are isolated from many severe infections $[42,128]$, they are infrequent in mild-to-moderate infections [14, 84, 129], and there is little evidence to support the need for antianaerobic therapy in most infections (B-III). For mild-to-moderate infections in patients without gastrointestinal absorption problems and for whom an oral agent with the appropriate spectrum is available, oral therapy is often appropriate, especially with highly bioavailable agents (A-II). For mildly infected open wounds with minimal cellulitis, limited data support the use of topical antimicrobial therapy (B-I) [130].

Antibiotics vary in how well they achieve effective concentrations in infected diabetic foot lesions [131-137]; this is associated with the pharmacodynamic properties of the specific agent and, especially, the arterial supply to the foot, rather than with diabetes [138]. There are surprisingly few published clinical trials of antibiotic therapy for diabetic foot infection. Several antibiotic trials involving patients with various complicated 
skin and soft-tissue infections have included some patients with diabetic foot infections. Table 7 provides a list of published clinical trials that focused on therapy of diabetic foot infections, either exclusively or as an identified subset of a larger study. The lack of standardization among these trials makes the comparison of outcomes of different regimens inappropriate. The differing definitions of infection severity and clinical end points that were used in these publications highlight the need to develop a consensus classification system for future studies. On the basis of the available studies, no single drug or combination of agents appears to be superior to others [129].

Table 8 summarizes some potential empirical antibiotic regimens according to the clinical severity of the infection, although the available data do not allow us to recommend any specific antibiotic regimen for diabetic foot infections (B-II). These suggested agents are derived from available published clinical trials and our collective experience and are not meant to be inclusive of all potentially reasonable regimens. Similar agents could be used, depending on various clinical, microbiological, epidemiological, and financial considerations. Consider modifying antibiotic therapy when culture and susceptibility results are available (C-III). Empirical choices for patients who are not responding to antibiotic therapy should include agents that cover a different or more-extended spectrum of organisms (B-III) (figure 3). The regimens in table 8 are listed in approximate order of increasing broad-spectrum coverage; the order does not indicate preferences by the committee. Dosages of antibiotic agents should be selected according to suggestions of the US Food and Drug Administration, the drug's manufacturers, and the experience of the prescriber and should be modified on the basis of any relevant organ (especially renal) dysfunction and other clinical factors.

Determine the need for surgery. Many infections require surgical procedures that range from drainage and excision of infected and necrotic tissues to revascularization of the lower extremity and reconstruction of soft-tissue defects or mechanical misalignments [164-168]. Unfortunately, surgical treatment of diabetic foot infections is based on even less-structured evidence than that for antibiotic therapy [169]. Seek urgent surgical consultation for life- or limb-threatening infections, such as those presenting with necrotizing fasciitis, gas gangrene, extensive soft-tissue loss, or evidence of compartment syndrome, or those in limbs with critical ischemia (A-II) [170, 171]. A surgical specialist should also evaluate patients who have unexplained persistent foot pain or tenderness and/or evidence of a deep-space infection, deep abscesses, or progressive infection in the face of apparently appropriate medical care (figure 3). Timely and aggressive surgical debridement, including limited resections or amputations, may reduce the need for more-extensive amputation (B-II) $[172,173]$. Pus under pressure, especially in an ischemic foot, can cause rapid and irrep- arable damage. For patients with less-serious infections, it may be appropriate to delay surgery to carefully observe the effectiveness of medical therapy or to determine the demarcation line between necrotic and viable tissue [174].

The surgeon must determine the adequacy of the blood supply to the remaining viable tissues, consider common operative pitfalls (e.g., infection spreading among foot compartments, to the deep plantar space, or along the tendon sheaths), and formulate a strategy for eventual soft-tissue cover (e.g., primary closure, delayed primary closure, secondary intention, or tissue transfer) [175-177]. The surgical approach should optimize the likelihood for healing and should attempt to preserve the integrity of the walking surface of the foot (B-II) [178]. In addition to manual dexterity, the surgeon must have sufficient knowledge and experience to judge when and how to intervene. The surgeon's training specialty is less important than his or her knowledge of the anatomy of the foot, the pathophysiology of ulceration and infection, and experience with and enthusiasm for the field [8]. In most instances, the surgeon should continue to observe the patient until the infection is under control and the wound is healing (B-III).

In some cases, amputation is the best or only option [170, 179]. Urgent amputation is usually required only when there is extensive necrosis or life-threatening infection [180]. Elective amputation may be considered for the patient who has recurrent ulceration (despite maximal preventive measures), has irreversible loss of foot function, or would require unacceptably prolonged or intensive hospital care [181, 182]. Selection of the level of amputation must take into consideration vascular, reconstructive, and rehabilitation issues [183, 184]. Generally, the surgeon should attempt to save as much of the limb as possible. However, a higher-level amputation that results in a more functional residual stump (even if a prosthesis is required) may be a better choice than preserving a foot that is mechanically unsound, unlikely to heal, or prone to future ulceration. When all or part of a foot has dry gangrene, it may be preferable (especially for a patient for whom surgery is a poor option) to let the necrotic portions autoamputate. It may also be best to leave adherent eschars in place, especially on the heel, until they soften enough to be more easily removed, provided there does not appear to be an underlying focus of infection [80, 81].

If the infected limb appears to be ischemic, the patient should be referred to a surgeon with vascular expertise [185]. In most cases, ischemia is due to larger-vessel atherosclerosis, rather than to "small-vessel disease" [68]. Because vessels above the knee and below the ankle tend to be relatively spared, lowerextremity atherosclerosis may be amenable to angioplasty or vascular bypass [186]. Patients with noncritical ischemia (e.g., those with an ankle to brachial artery blood pressure index of $0.5-0.9$ ) can usually be successfully treated without a vascular 
Table 7. Antibiotic agents used in published clinical studies of diabetic foot infections.

\begin{tabular}{|c|c|c|c|c|c|}
\hline Antibiotic (route) & $\begin{array}{l}\text { No. of } \\
\text { treated } \\
\text { patients }\end{array}$ & Study design & Patient group & $\begin{array}{l}\text { Type/severity of } \\
\text { infection(s) }\end{array}$ & Reference \\
\hline \multicolumn{6}{|l|}{ Cephalosporins } \\
\hline Cefoxitin (iv) & 8 & $\begin{array}{l}\text { Prospective, } \\
\text { noncomparative }\end{array}$ & Hospitalized & Presumptive anaerobic & {$[139]$} \\
\hline Cefoxitin (iv) & 23 & RDBCT & Hospitalized & Moderate-to-severe & {$[140]$} \\
\hline Cefoxitin (iv) & 60 & $\begin{array}{l}\text { Prospective, } \\
\text { noncomparative }\end{array}$ & Hospitalized & $\begin{array}{l}\text { Failing to respond to } \\
\text { therapy }\end{array}$ & {$[141]$} \\
\hline Cefoxitin (iv) & 18 & $\mathrm{RDBCT}$ & Hospitalized & Mild-to-severe & [142] \\
\hline Cefoxitin (iv) alone & 12 & $\mathrm{RCT}$ & Hospitalized & Mixed & [143] \\
\hline $\begin{array}{l}\text { Cefoxitin (iv) and amdino- } \\
\text { cillin (iv) }\end{array}$ & 13 & $\mathrm{RCT}$ & Hospitalized & Mixed & [143] \\
\hline Ceftizoxime (iv) & 20 & Prospective, uncontrolled & Hospitalized & PVD, moderate-to-severe & {$[144]$} \\
\hline Ceftizoxime (iv) & 23 & $\mathrm{RDBCT}$ & Hospitalized & Moderate-to-severe & {$[140]$} \\
\hline Cephalexin (po) & 29 & RDBCT & Outpatient & Mild-to-moderate & [84] \\
\hline Ceftriaxone (iv) & 90 & Prospective, observational & Hospitalized & Severe limb-threatening & [145] \\
\hline \multicolumn{6}{|l|}{ Penicillins } \\
\hline $\begin{array}{l}\text { Ampicillin/sulbactam (iv) } \\
\text { (then amoxicillin/clavu- } \\
\text { lanate [po]) }\end{array}$ & 53 & $\mathrm{RCT}$ & Hospitalized initially & Moderate & [146] \\
\hline Ampicillin/sulbactam (iv) & 48 & RDBCT & Hospitalized & Limb-threatening & [147] \\
\hline Ampicillin/sulbactam (iv) & 74 & $\begin{array}{l}\text { Prospective, } \\
\text { noncomparative }\end{array}$ & Hospitalized & Moderate-to-severe & {$[148]$} \\
\hline Ampicillin/sulbactam (iv) & 18 & $\mathrm{RDBCT}$ & Hospitalized & Mild-to-severe & [142] \\
\hline $\begin{array}{l}\text { Ampicillin/sulbactam (iv) } \\
\text { and/or amoxicillin/clavu- } \\
\text { lanate (po) }\end{array}$ & 120 & $\mathrm{RCT}$ & Outpatient or hospitalized & All types & [121] \\
\hline Amoxicillin/clavulanate (iv/po) & 191 & $\begin{array}{l}\text { Observational, } \\
\text { noncomparative }\end{array}$ & Mostly hospitalized & Moderate & [149] \\
\hline Ticarcillin/clavulanate (iv) & 28 & RCT subgroup ${ }^{a}$ & Inpatient or outpatient & Complicated soft-tissue & {$[150]$} \\
\hline Ticarcillin/clavulanate (iv) & 17 & RCT subgroup ${ }^{a}$ & Hospitalized & Complicated soft-tissue & {$[151]$} \\
\hline Piperacillin/tazobactam (iv) & 29 & $\begin{array}{l}\text { Prospective, } \\
\text { noncomparative }\end{array}$ & Hospitalized & Moderate-to-severe & [152] \\
\hline $\begin{array}{l}\text { Piperacillin/tazobactam } \\
\text { (iv/im) }\end{array}$ & 38 & $\begin{array}{l}\text { Prospective } \\
\text { noncomparative }\end{array}$ & Outpatient & $\begin{array}{l}\text { Parenteral, mostly } \\
\text { moderate }\end{array}$ & [153] \\
\hline Piperacillin/tazobactam (iv) & 34 & RDBCT subgroup ${ }^{a}$ & Hospitalized & Severe & [154] \\
\hline \multicolumn{6}{|l|}{ Fluoroquinolones } \\
\hline Ciprofloxacin (po) & 46 & $\begin{array}{l}\text { Prospective, randomized } \\
\text { doses }\end{array}$ & Hospitalized & PVD & [155] \\
\hline Ciprofloxacin (iv, then po) & 43 & $\begin{array}{l}\text { Prospective, } \\
\text { noncomparative }\end{array}$ & Hospitalized & Soft-tissue or bone & [156] \\
\hline $\begin{array}{l}\text { Ciprofloxacin (po) and } \\
\text { clindamycin (po) }\end{array}$ & 120 & $\begin{array}{l}\text { Uncontrolled, quasi- } \\
\text { prospective }\end{array}$ & $\begin{array}{l}\text { Hospitalized initially, re- } \\
\text { ceived other iv agents, } \\
\text { and was then dis- } \\
\text { charged home }\end{array}$ & Moderate-to-severe & [157] \\
\hline Ofloxacin (iv, then po) & 55 & $\mathrm{RCT}$ & Hospitalized initially & Moderate & [146] \\
\hline Ofloxacin (po) & 420 & RDBCT & Outpatients & $\begin{array}{l}\text { Mild-to-moderately } \\
\text { infected ulcers }\end{array}$ & {$[130]$} \\
\hline Levofloxacin (iv or po) & 26 & RCT subgroup ${ }^{a}$ & Outpatients or inpatients & Complicated soft-tissue & {$[150]$} \\
\hline Trovafloxacin (po) & 214 & $\begin{array}{l}\text { Prospective, } \\
\text { noncomparative }\end{array}$ & $\ldots$ & Soft-tissue & [158] \\
\hline Clinafloxacin (iv, then po) & 42 & RDBCT subgroup $^{a}$ & Hospitalized & Severe & {$[154]$} \\
\hline $\begin{array}{l}\text { Ofloxacin, levofloxacin, or } \\
\text { ciprofloxacin (iv and/or po) }\end{array}$ & 90 & Prospective, observational & Hospitalized & Severe limb-threatening & [145] \\
\hline \multicolumn{6}{|l|}{ Carbapenems } \\
\hline Imipenem/cilastatin (iv) & 48 & $\mathrm{RDBCT}$ & Hospitalized & Limb-threatening & [147] \\
\hline Imipenem/cilastatin (iv) & 94 & $\begin{array}{l}\text { Uncontrolled, } \\
\text { noncomparative }\end{array}$ & Hospitalized & Moderate-to-severe & [159] \\
\hline Imipenem/cilastatin (iv) & 22 & $\begin{array}{l}\text { Randomized, open, } \\
\text { comparative }\end{array}$ & Hospitalized & $\begin{array}{l}\text { Wagner grade } 2-4 \\
\text { wounds }\end{array}$ & {$[160]$} \\
\hline Ertapenem (iv) & 33 & $\mathrm{RDBCT}$ & Hospitalized & Complicated soft-tissue & [161] \\
\hline
\end{tabular}


Table 7. (Continued.)

\begin{tabular}{|c|c|c|c|c|c|}
\hline Antibiotic (route) & $\begin{array}{l}\text { No. of } \\
\text { treated } \\
\text { patients }\end{array}$ & Study design & Patient group & $\begin{array}{l}\text { Type/severity of } \\
\text { infection(s) }\end{array}$ & Reference \\
\hline \multicolumn{6}{|l|}{ Miscellaneous agents } \\
\hline Aztreonam (iv) & 20 & Prospective subgroup $^{a}$ & Hospitalized & Acute, severe soft-tissue & [162] \\
\hline Clindamycin (po) & 29 & RDBCT & Outpatient & Mild-to-moderate & {$[84]$} \\
\hline Piperacillin/clindamycin (iv) & 24 & $\begin{array}{l}\text { Randomized, open, } \\
\text { comparative }\end{array}$ & Hospitalized & $\begin{array}{l}\text { Wagner grade } 2-4 \\
\text { wounds }\end{array}$ & {$[160]$} \\
\hline Pexiganan (topical) & 415 & RDBCT & Outpatient & $\begin{array}{l}\text { Mild-to-moderate infected } \\
\text { ulcers }\end{array}$ & [130] \\
\hline Linezolid (iv or po) & 241 & $\mathrm{RCT}$ & Outpatient or hospitalized & All types & [121] \\
\hline Daptomycin (iv) & 50 & RCT subgroup ${ }^{a}$ & Hospitalized & Complicated skin & [163] \\
\hline
\end{tabular}

NOTE. Trials are those in which the purpose of the study was to examine the efficacy of antibiotic therapy, and the subjects were exclusively, predominantly, or separately identifiable as diabetic patients with foot infections. The clinical and microbiological outcomes were not consistently defined or routinely provided. PVD, peripheral vascular disease; RCT, randomized controlled trial; RDBCT, randomized, double-blinded, controlled trial (each arm is listed separately in the table).

a Involved patients with diabetic foot infections who constituted an identified subgroup of a larger trial of skin and skin structure infections.

procedure. For more-severe vascular disease of the foot, many centers have reported successful use of femoral-distal bypass procedures in diabetic patients [186-189]. For a patient with a severely infected ischemic foot, it is usually preferable to perform any needed revascularization early after recognizing the infection (i.e., within 1-2 days), rather than to delay this procedure in favor of prolonged (and potentially ineffective) antibiotic therapy (B-II) $[123,190]$. On the other hand, careful debridement of necrotic infected material should not be delayed while awaiting revascularization. Optimal surgical management may require multiple, staged procedures [191].

Formulate a wound-care plan. The wound may require additional attention after the debridement performed during the initial assessment (table 4). The goal is to physically excise dead and unhealthy tissue, thereby enabling wound healing and removing a reservoir of potential pathogens [82, 192-194]. Any experienced clinician may perform limited debridement. This can usually be undertaken as a clinic or bedside procedure and without anesthesia, especially for a neuropathic foot. Sharp debridement with scalpel, scissors, or tissue nippers is generally preferable to hydrotherapy or topical debriding agents, which are less definitive and controllable and may require prolonged and repeated applications (B-III) [194, 195]. There are many wound-care products that are touted as being able to improve healing in various ways [17, 23, 196-199], but a discussion of these is beyond our scope. The infected wound should be dressed in a manner that allows daily inspection and encourages a moist wound-healing environment (B-III). No evidence favors any particular type of dressing; convenience and cost are important considerations. Removal of pressure from a foot wound (i.e., off-loading) is crucial to the healing process (AI) $[200,201]$. Many types of devices can off-load the infected wound, but it is important to choose one that permits easy inspection [202].

Adjunctive treatments. Investigators and industry repre- sentatives have advocated many types of wound-care treatments, including wound vacuum-drainage systems [203-206], recombinant growth factors [207-212], skin substitutes [203, 213-216], antimicrobial dressings [217-219], and maggot (sterile larvae) therapy [220-222]. Although each treatment likely has some appropriate indications, for infected wounds, available evidence is insufficient to recommend routine use of any of these modalities for treatment or prophylaxis.

Two adjunctive modalities do deserve brief comments. First, granulocyte colony-stimulating factors (G-CSFs) have now been investigated in 5 randomized trials involving diabetic foot infections [223-227]. A preliminary meta-analysis of these trials suggests that G-CSF does not accelerate resolution of infection but may significantly reduce the need for operative procedures (B-I) [228]. Second, several anecdotal and retrospective reports suggest that hyperbaric oxygen therapy may be of value for treatment of diabetic foot wounds, and a few recent prospective studies have shown promising results [229-232]. A recent Cochrane review concluded that hyperbaric oxygen therapy significantly reduced the risk of major amputation related to a diabetic foot ulcer [233] (B-I). Only additional randomized clinical trials can establish when, for whom, and with what protocols these expensive and limited resources might be used in the treatment of diabetic foot infections. Neither should be used as a substitute for proper surgical debridement and conventional therapy.

\section{FOLLOW-UP}

Careful observation of the patient's response to therapy (figure 4 ) is essential and should be performed daily for inpatients and perhaps every 2-5 days initially for outpatients (B-III). The primary indicators of improvement are resolution of local and systemic symptoms and clinical signs of inflammation. Blood test findings, including WBC counts $[234,235]$ and inflam- 
Table 8. Suggested empirical antibiotic regimens, based on clinical severity, for diabetic foot infections.

\begin{tabular}{|c|c|c|c|}
\hline Route and agent(s) & Mild & Moderate & Severe \\
\hline Advised route & Oral for most & $\begin{array}{l}\text { Oral or parenteral, based } \\
\text { on clinical situation and } \\
\text { agent(s) selected }\end{array}$ & $\begin{array}{l}\text { Intravenous, at least } \\
\text { initially }\end{array}$ \\
\hline Dicloxacillin & Yes & $\ldots$ & $\ldots$ \\
\hline Clindamycin & Yes & $\ldots$ & $\ldots$ \\
\hline Cephalexin & Yes & $\ldots$ & $\ldots$ \\
\hline Trimethoprim-sulfamethoxazole & Yes & Yes & $\ldots$ \\
\hline Amoxicillin/clavulanate & Yes & Yes & $\ldots$ \\
\hline Levofloxacin & Yes & Yes & $\ldots$ \\
\hline Cefoxitin & $\ldots$ & Yes & $\ldots$ \\
\hline Ceftriaxone & $\ldots$ & Yes & $\ldots$ \\
\hline Ampicillin/sulbactam & $\ldots$ & Yes & $\ldots$ \\
\hline Linezolid $^{\mathrm{a}}$ (with or without aztreonam) & $\ldots$ & Yes & $\ldots$ \\
\hline Daptomycin (with or without aztreonam) & $\ldots$ & Yes & $\ldots$ \\
\hline Ertapenem & $\ldots$ & Yes & $\ldots$ \\
\hline Cefuroxime with or without metronidazole & $\ldots$ & Yes & $\ldots$ \\
\hline Ticarcillin/clavulanate & $\ldots$ & Yes & $\ldots$ \\
\hline Piperacillin/tazobactam & $\ldots$ & Yes & Yes \\
\hline Levofloxacin or ciprofloxacin with clindamycin & $\ldots$ & Yes & Yes \\
\hline Imipenem-cilastatin & $\ldots$ & $\ldots$ & Yes \\
\hline $\begin{array}{l}\text { Vancomycin }{ }^{\mathrm{a}} \text { and ceftazidime (with or without } \\
\text { metronidazole) }\end{array}$ & $\ldots$ & $\ldots$ & Yes \\
\hline
\end{tabular}

NOTE. Definitive regimens should consider results of culture and susceptibility tests, as well as the clinical response to the empirical regimen. Similar agents of the same drug class may be substituted. Some of these regimens may not have US Food and Drug Administration approval for complicated skin and skin-structure infections, and only linezolid is currently specifically approved for diabetic foot infections.

${ }^{a}$ For patients in whom methicillin-resistant $S$. aureus infection is proven or likely.

matory markers, such as the erythrocyte sedimentation rate $[122,236,237]$ and the C-reactive protein level [238], are of limited use for monitoring response, although is it reassuring to see elevated levels decrease and cause for concern when they do not.

When a hospitalized patient is ready for discharge or an outpatient returns for follow-up, the clinician should accomplish 4 tasks (figures 1, 2, and 4).

1. Select the definitive antibiotic regimen. Review the culture and drug susceptibility results and inquire about any adverse effects related to the current antibiotic therapy. Choose a definitive antibiotic regimen (including the treatment duration) on the basis of the results of cultures, imaging, or other investigations, and the initial clinical response (C-III). It is not always necessary to cover all microorganisms isolated from cultures. More virulent species (e.g., S. aureus and group A or B streptococci) should always be covered, but in a polymicrobial infection, less-virulent bacteria (e.g., coagulase-negative staphylococci and enterococci) may be less important (B-II). If the infection has not responded to the empirical regimen, select agents with activity against all isolates. For a clinically stable patient who has had $\geqslant 1$ unsuccessful courses of therapy, con- sider discontinuing antimicrobials for a few days and then collecting optimal specimens for culture (C-III).

2. Re-evaluate the wound. Inspect the site to ensure that the infection is responding and that the wound is healing. If neither is occurring, reassess the need for surgical intervention. No evidence supports giving antibiotics for the entire time that the wound remains open. Antibiotics should be used for a period defined by the biology of the infection and by the clinical syndrome, as suggested in table 9 (A-II). If clinical evidence of infection persists beyond the expected duration, check on the patient's compliance with antibiotics and re-evaluate for unaddressed adverse biological factors (figure 3). These may include the development of antibiotic resistance, a superinfection, an undiagnosed deep abscess or case of osteomyelitis, or ischemia that is more severe than was initially suspected.

3. Review the off-loading and wound care regimens. Determine the effectiveness of, and the patient's compliance with, the prescribed regimens. Suggest (or seek consultation for) alternatives when necessary.

4. Evaluate glycemic control. Ensure that blood glucose levels and other aspects of the patient's metabolic status are adequately controlled. 


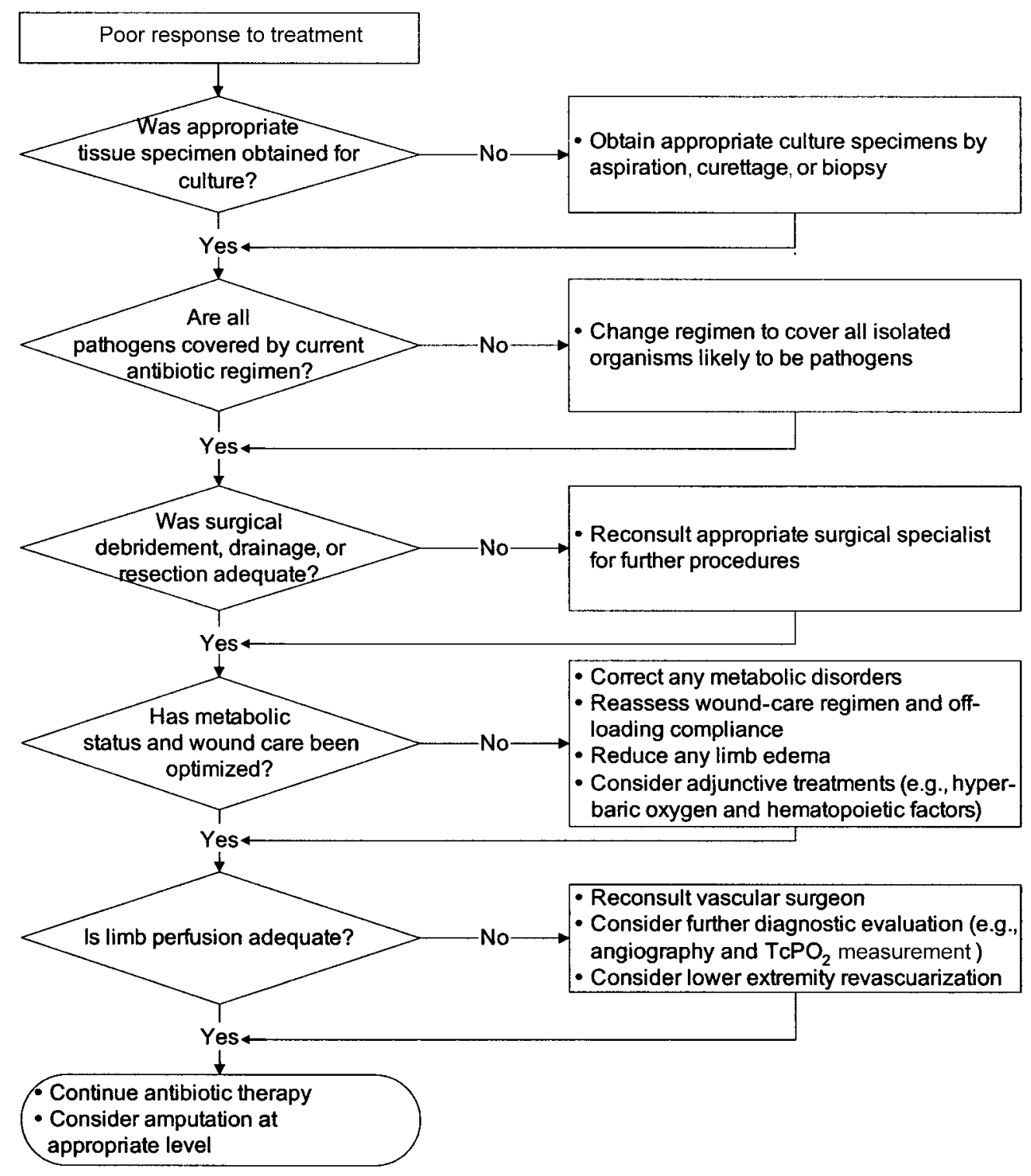

Figure 3. Algorithm 1, part 3: approach to assessing a diabetic patient with a foot infection who is not responding well to treatment. $\mathrm{TcPO}_{2}$, transcutaneous partial pressure of $\mathrm{O}_{2}$.

\section{OSTEOMYELITIS}

Dealing with osteomyelitis is perhaps the most difficult and controversial aspect in the management of diabetic foot infections [239-244]. First among several problems is that the lack of a consensus definition of the disease hinders the comparison of available studies and experiences. Next, there are many available diagnostic tests, but they often yield equivocal results. Furthermore, the presence of osteomyelitis increases the likelihood of surgical intervention, including amputation, and the required duration of antibiotic therapy [240]. Finally, osteomyelitis impairs healing of the overlying wound and acts as a focus for recurrent infection.
When to consider the diagnosis. Consider osteomyelitis as a potential complication of any deep or extensive ulcer, especially one that is chronic or overlies a bony prominence (figure 5) [245]. Suspect underlying osteomyelitis when an ulcer does not heal after at least 6 weeks of appropriate care and offloading. Any ulcer in which bone is either visible or can be easily palpated with a sterile blunt metal probe is likely to be complicated by osteomyelitis [83]. In patients with a limbthreatening infection, positive results of a probe-to-bone test may be taken as nearly sufficient for diagnosis, but the performance characteristics of this test have not yet been fully defined. A swollen foot in a patient with a history of foot 


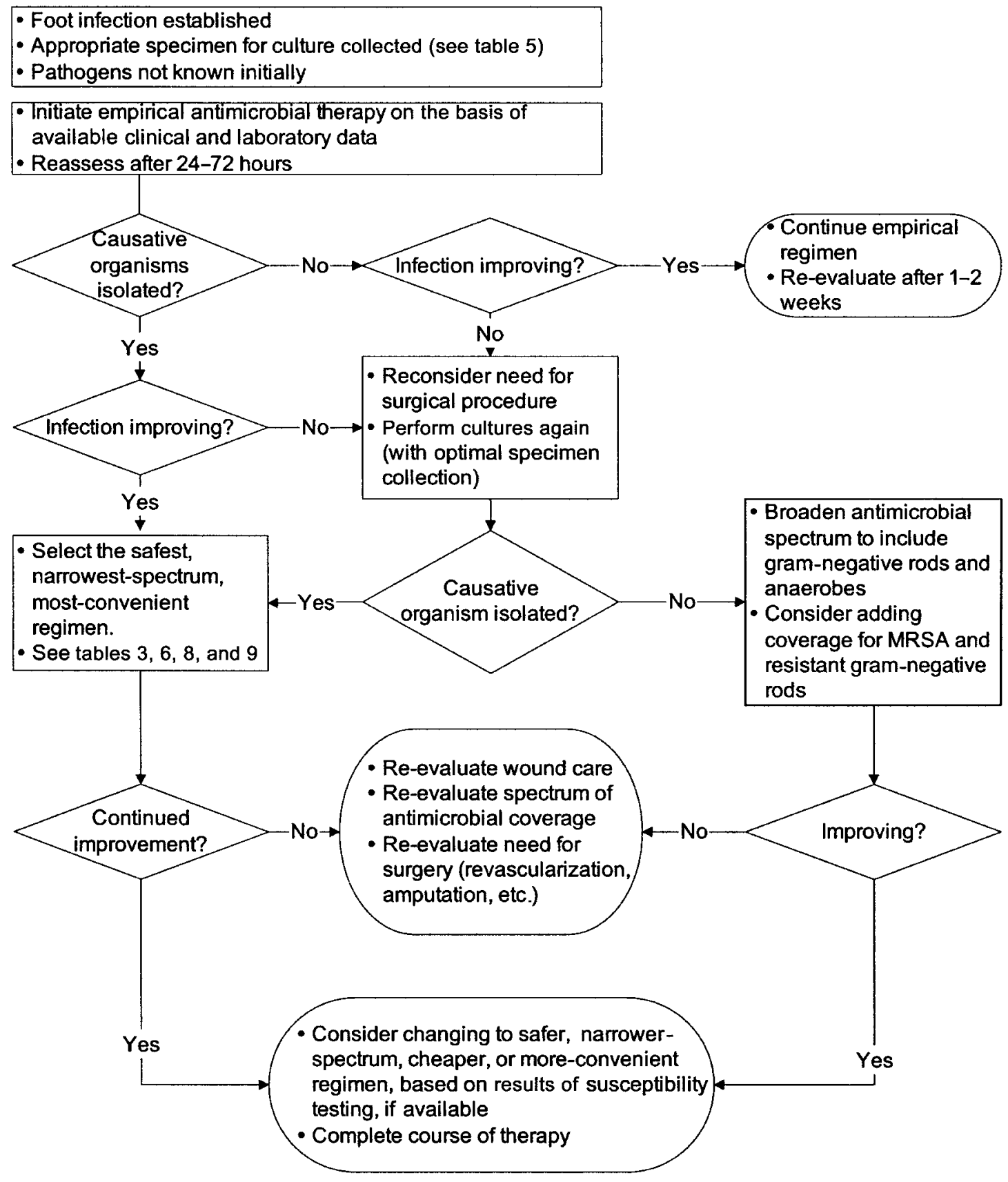

Figure 4. Algorithm 2: approach to selecting antibiotic therapy for a diabetic patient with a foot infection. MRSA, methicillin-resistant Staphylococcus aureus.

ulceration, a "sausage toe" (i.e., a red, swollen digit) [246], or an unexplained high WBC count [235] or inflammatory markers [236] should also arouse suspicion of osteomyelitis (B-II). Finally, radiologically evident bone destruction beneath an ulcer should be considered to represent osteomyelitis unless proven otherwise [247].

Confirming the diagnosis. Because bony destruction is usually not seen on plain radiography performed during the early stages of disease and neuro-osteoarthropathy can mimic infection, diagnosing osteomyelitis at the time the patient first presents to the hospital can be difficult [248-250]. Characteristic progressive changes on serial plain radiographs may help in more-chronic cases [247, 251]. Radioisotope scans are more sensitive than radiographs for detecting osteomyelitis during the early stages of this diseases, but they are expensive and can be time-consuming [252]. The reported performance characteristics of various types of nuclear medicine scans varies, but the specificity of technetium bone scans is generally low [240, 
Table 9. Suggested route, setting, and durations of antibiotic therapy, by clinical syndrome.

\begin{tabular}{|c|c|c|c|}
\hline $\begin{array}{l}\text { Site, by severity or } \\
\text { extent, of infection }\end{array}$ & Route of administration & Setting for therapy & Duration of therapy \\
\hline \multicolumn{4}{|l|}{ Soft-tissue only } \\
\hline Mild & Topical or oral & Outpatient & $\begin{array}{l}\text { 1-2 Weeks; may extend } \\
\text { up to } 4 \text { weeks if slow } \\
\text { to resolve }\end{array}$ \\
\hline Moderate & Oral (or initial parenteral) & Outpatient/inpatient & 2-4 Weeks \\
\hline Severe & $\begin{array}{l}\text { Initial parenteral, switch to oral } \\
\text { when possible }\end{array}$ & $\begin{array}{l}\text { Inpatient, then } \\
\text { outpatient }\end{array}$ & 2-4 Weeks \\
\hline \multicolumn{4}{|l|}{ Bone or joint } \\
\hline $\begin{array}{c}\text { No residual infected tissue } \\
\text { (e.g., post-amputation) }\end{array}$ & Parenteral or oral & $\ldots$ & 2-5 Days \\
\hline $\begin{array}{l}\text { Residual infected soft tissue } \\
\text { (but not bone) }\end{array}$ & Parenteral or oral & $\cdots$ & 2-4 Weeks \\
\hline $\begin{array}{l}\text { Residual infected (but viable) } \\
\text { bone }\end{array}$ & $\begin{array}{l}\text { Initial parenteral, then consider } \\
\text { oral switch }\end{array}$ & $\ldots$ & 4-6 Weeks \\
\hline $\begin{array}{l}\text { No surgery, or residual dead } \\
\text { bone postoperatively }\end{array}$ & $\begin{array}{l}\text { Initial parenteral, then consider } \\
\text { oral switch }\end{array}$ & $\ldots$ & $>3$ Months \\
\hline
\end{tabular}

253-255]. MRI is the most useful of the currently available imaging modalities (A-I) [90, 92, 94, 256-259]. MRI is the most accurate imaging study for defining bone infection, and it also provides the most reliable image of deep soft-tissue infections. The performance characteristics of all these diagnostic tests are highly correlated with the pretest probability of osteomyelitis, and they are most useful for intermediately probable cases [260]. The criterion (gold) standard for diagnosing osteomyelitis is isolation of bacteria from a reliably obtained sample of bone (using measures to minimize contamination) concomitant with histological findings of inflammatory cells and osteonecrosis (B-II). Unfortunately, few of the studies that have evaluated diagnostic tests or have assessed treatment outcomes have used this standard.

MRI is usually not needed as a first-line investigation in cases of diabetic foot infection. When osteomyelitis is a possibility, obtaining plain radiographs often suffices. If these radiographs show no evidence of pathological findings in bone, the patient should be treated for $\sim 2$ weeks for the soft-tissue infection. If suspicion of osteomyelitis persists, perform plain radiography again 2-4 weeks later. If the initial films show classic changes suggestive of osteomyelitis (cortical erosion, periosteal reaction, and mixed lucency and sclerosis), and if there is little likelihood of a noninfectious osteoarthropathy, treat for presumptive osteomyelitis, preferably after obtaining appropriate specimens for culture (B-III). If findings of radiography are only consistent with, but not characteristic of, osteomyelitis, one of the following choices should be considered.

1. Additional imaging studies. MRI is the preferred imaging study, with nuclear medicine scans (that preferably use newer generation leukocyte $[239,261,262]$ or immunoglobulin [263, 264 ] techniques) being a second choice. If results of the imaging tests are negative, osteomyelitis is unlikely; if results suggest osteomyelitis, consider whether bone biopsy is needed (vide infra).

2. Empirical treatment. Provide antibiotic therapy for another 2-4 weeks and then perform radiograph again to determine whether bony changes have progressed (which would suggest infection).

3. Bone biopsy. Use an appropriate procedure, as defined below. Collection of a sample of a bony lesion (either operatively or percutaneously) is recommended if the diagnosis remains in doubt after imaging or if osteomyelitis is likely but the etiologic agent or antibiotic susceptibilities are not predictable (B-II) [251, 265-268]. Some physicians would also obtain biopsy specimens of most mid- or hind-foot lesions, because these are more difficult to treat and more often lead to a high-level (i.e., above the ankle) amputation. Any properly trained physician (e.g., an orthopedic surgeon, podiatrist, interventional radiologist) can perform the biopsy. Percutaneous biopsy should preferably be done under fluoroscopic or CT guidance, traversing uninvolved skin if possible. For patients with sensory neuropathy, anesthesia may be unnecessary. Various types of bone-cutting needles, such as Jamshidi (Perfectum Corporation; distributed by Propper and Sons) and Ostycut (Bard Products; distributed by Angiomed) have been used. Obtain 2-3 specimens if possible, sending at least 1 for culture and another for histological analysis [269]. With small toe bones, it may only be possible to aspirate a few bony spicules. We found no published reports of complications of foot bone biopsy and consider it to be a safe procedure (B-II). Cultures of bone specimens provide more accurate microbiologic data than do those of soft-tissue specimens for patients with osteomyelitis [93, 268, 270]. 


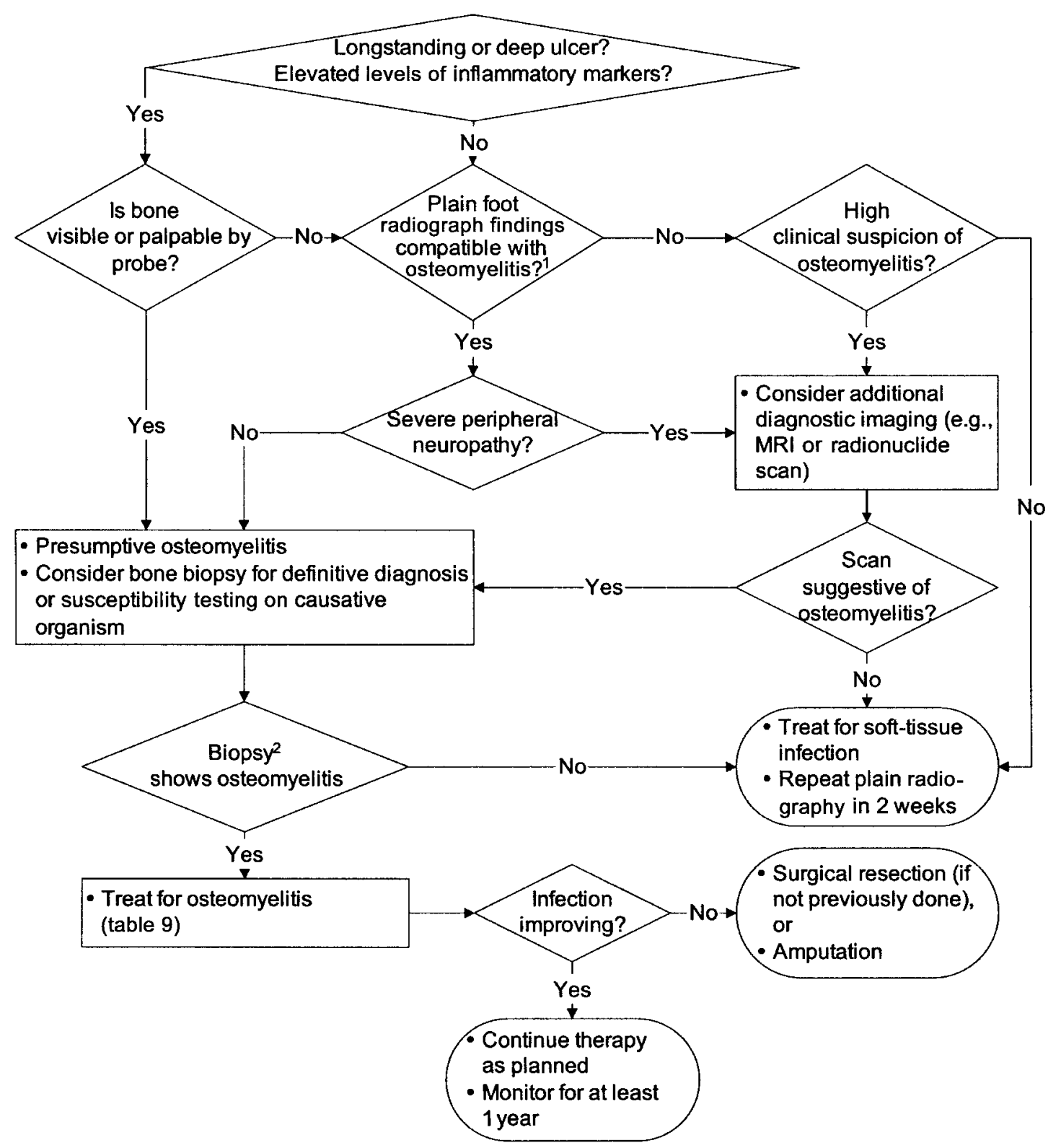

Figure 5. Algorithm 3: evaluating a diabetic patient who has suspected osteomyelitis of the foot. ${ }^{1}$ Cortical erosion, periosteal reaction, lucency and sclerosis, sequestrum, or involcrum. ${ }^{2}$ May be done percutaneously or operatively, preferably after antibiotic therapy has been stopped for $1-2$ weeks (if safe to do so).

Choosing between medical and surgical therapy. Traditionally, authorities have believed that resecting a bone with chronic osteomyelitis was essential for cure [240, 265]. Recently, some have disputed the routine need for surgical resection [239]. Definitive surgical solutions to osteomyelitis, such as ray and transmetatarsal amputations, may risk architectural reorganization of the foot, resulting in altered biomechanics and additional cycles of ulceration. Neuropathy and reduced systemic manifestations of infection may make osteomyelitis tolerable for the patient, who may thus opt for attempts at medical management. By contrast, these diabetic complications may also mask progressive bone destruction, with delayed or inadequate surgery resulting in poorly controlled infection, additional bone or soft-tissue necrosis, and a nonhealing wound.

These arguments have led some health care professionals to treat diabetic foot osteomyelitis with little or no surgical intervention [239]. Published reports on nonsurgical treatment with a prolonged (3-6 months) course of antibiotics have reported clinical success in $\sim 65 \%-80 \%$ of cases $[155,173,237$, 243, 271-276]. Unfortunately, these nonrandomized case series often fail to specify a definition of osteomyelitis, how patients were selected, whether patients were enrolled prospectively or 
even consecutively, and how much nonoperative debridement of bone was performed. The determination of which patients are suitable for nonsurgical treatment, as well as what duration of antibiotic therapy is needed, are important areas for future study. Meanwhile, there are 4 cases in which nonsurgical management of osteomyelitis might be considered (B-II).

1. There is no acceptable surgical target (i.e., radical cure of the infection would cause unacceptable loss of function).

2. The patient has ischemia caused by unreconstructable vascular disease but desires to avoid amputation.

3. Infection is confined to the forefoot, and there is minimal soft-tissue loss.

4. The patient and health care professional agree that surgical management carries excessive risk or is otherwise not appropriate or desirable.

When therapy for osteomyelitis fails, consider several issues. First, was the original diagnosis correct? Second, is there residual necrotic or infected bone or surgical hardware that should be resected or removed? Third, did the selected antibiotic regimen likely cover the causative organism(s) and achieve adequate levels in bone, and was it administered for a sufficient duration? Fourth, was the failure to eradicate bone infection the real cause of the current wound problem? Each case needs an individualized approach, usually in consultation with a knowledgeable surgeon. Selected patients may benefit from implanted antibiotics (e.g., embedded in beads or cement) [277-280], hyperbaric oxygen therapy, or revascularization, whereas others may elect long-term or intermittent antibiotic suppression or, in some cases, amputation.

Selecting an antibiotic regimen. The most appropriate duration of therapy for any type of diabetic foot infection has not been well defined [129]. It is important to consider the presence and amount of any residual dead or infected bone and the state of the soft tissues. When a radical resection leaves no remaining infected tissue, minimal antibiotic therapy is needed (B-II). Alternatively, if infected bone or soft tissue remain despite surgery, continued prolonged treatment is necessary. For osteomyelitis, some parenteral therapy may be beneficial, especially if an agent with suboptimal bioavailability is used (C-III). Parenteral therapy may be delivered in the outpatient setting, where available [153, 281, 282]. Our recommendations for duration of therapy are based on the clinical syndrome and are summarized in table 9.

\section{OUTCOMES}

The goals of treating a diabetic foot infection are the eradication of clinical evidence of infection and the avoidance of soft-tissue loss and amputations. Overall, expect a good clinical response (i.e., resolution of clinical evidence of infection) to appropriate therapy in $80 \%-90 \%$ of mild-to-moderate infections [84, 121 ,
$130,263]$ and in $60 \%-80 \%$ of severe infections or cases of osteomyelitis [130, 145, 147, 237, 283]. Factors associated with a poor outcome include signs of systemic infection [237], inadequate limb perfusion, osteomyelitis [273, 283-285], the presence of necrosis or gangrene [276], an inexperienced surgeon [286], and proximal location of the infection [287]. Relapses occur in $\sim 20 \%-30 \%$ of patients, especially in those with osteomyelitis; relapses may be difficult to differentiate from a reinfection. A recent survey of members of the Emerging Infections Network found that the acceptable median failure rate for treating diabetic foot osteomyelitis was $18 \%$ [288]. Conducting systematic audits of outcomes and patient treatment processes may be useful for individual practitioners and for multidisciplinary foot-care teams (B-II).

\section{PREVENTION}

A patient who has had 1 foot infection is more likely to have another, making this a good time to reinforce preventive actions with the patient $[11,289,290]$. Detection of neuropathy before its complications ensue is the best method to prevent foot infections. Educate the patient about the importance of optimizing glycemic control, using appropriate footwear at all times, avoiding foot trauma, performing daily self-examination of the feet, and reporting any changes to health care professionals (A-II). Because basic screening can be completed in a few minutes, clinicians should reinforce these preventive measures by questioning patients about foot care and regularly examining their feet and shoes. Patients with severe neuropathy, substantial foot deformity, or critical ischemia should be referred to appropriate specialists to deal with these problems (A-II).

\section{RECOMMENDED RESEARCH}

Few of the recommendations in this guideline are based on properly designed and adequately powered randomized studies. There are 6 areas in which future research would be particularly helpful (A-III).

1. Establish a robust, validated, simple classification system for infected foot lesions to facilitate multicenter comparative studies of their natural history, diagnosis, and treatment. We support efforts to validate the International Consensus PEDIS system for foot-ulcer research purposes.

2. Determine whether there is a role for antibiotic therapy in managing clinically uninfected ulcers.

3. Determine optimal antibiotic regimens (agents, routes, and duration) for various types of soft-tissue and bone infections.

4. Establish a consensus definition of osteomyelitis in the diabetic foot.

5. Design and validate a simple, cost-effective algorithm 
for the diagnosis and treatment of infections, especially osteomyelitis.

6. Compare the outcomes of surgical and nonsurgical management of osteomyelitis.

\section{Acknowledgments}

Conflict of interest. B.A.L.: Advisory board membership, research support from, or speaker's bureau for Pfizer, Merck, Wyeth-Ayerst, Cubist, Vicuron, and Ortho-McNeil. A.R.B.: Speaker's bureau for Pfizer. H.G.D.: Speaker's bureau for GlaxoSmithKline and Pfizer, and research support from Theravance. J.M.E.: Advisory board membership, research support from, or speaker's bureau for AstraZeneca, Bayer, Bristol-Myers Squibb, Eli Lilly, Fujisawa, Janssen Ortho, and Pfizer. W.S.J.: Consultant and speaker's bureau for Pfizer and Merck. A.W.K.: Research support from Bayer, Pfizer, Merck, Ortho-McNeil, Cubist, Pharmacia, Vicuron, and Fujisawa and advisory board for Aventis, Pfizer, King Pharmaceuticals, Chiron, Vicuron, Cubist, and Bayer. C.N.: Former employee of Pfizer. J.S.T.: Research support from and speaker's bureau for Wyeth, Merck, Pfizer, OrthoMcNeil, Bayer, and Glaxo-SmithKline. J.L.L. and D.P.L.: No conflict.

\section{References}

1. Lipsky BA. A report from the international consensus on diagnosing and treating the infected diabetic foot. Diabetes Metab Res Rev 2004; 20(Suppl 1):S68-77.

2. Jeffcoate WJ, Harding KG. Diabetic foot ulcers. Lancet 2003;361: $1545-51$.

3. Tennvall GR, Apelqvist J, Eneroth M. Costs of deep foot infections in patients with diabetes mellitus. Pharmacoeconomics 2000; 18 : 225-38.

4. Ramsey SD, Newton K, Blough D, et al. Incidence, outcomes, and cost of foot ulcers in patients with diabetes. Diabetes Care 1999; 22: 382-7.

5. Reiber GE. The epidemiology of diabetic foot problems. Diabet Med 1996; 13(Suppl 1):S6-11.

6. Reiber GE, Vileikyte L, Boyko EJ, et al. Causal pathways for incident lower-extremity ulcers in patients with diabetes from two settings. Diabetes Care 1999; 22:157-62.

7. Pecoraro RE, Reiber GE, Burgess EM. Pathways to diabetic limb amputation: basis for prevention. Diabetes Care 1990; 13:513-21.

8. Crane M, Werber B. Critical pathway approach to diabetic pedal infections in a multidisciplinary setting. J Foot Ankle Surg 1999; 38 : 30-3; discussion 82-3.

9. Todd WF, Armstrong DG, Liswood PJ. Evaluation and treatment of the infected foot in a community teaching hospital. J Am Podiatr Med Assoc 1996; 86:421-6.

10. Dargis V, Pantelejeva O, Jonushaite A, Vileikyte L, Boulton AJ. Benefits of a multidisciplinary approach in the management of recurrent diabetic foot ulceration in Lithuania: a prospective study. Diabetes Care 1999; $22: 1428-31$.

11. Schaper NC, Apelquist J, Bakker K. The international consensus and practical guidelines on the management and prevention of the diabetic foot. Curr Diab Rep 2003; 3:475-9.

12. Ragnarson Tennvall G, Apelqvist J. Prevention of diabetes-related foot ulcers and amputations: a cost-utility analysis based on Markov model simulations. Diabetologia 2001;44:2077-87.

13. Armstrong DG, Harkless LB. Outcomes of preventative care in a diabetic foot specialty clinic. J Foot Ankle Surg 1998;37:460-6.

14. Armstrong DG, Liswood PJ, Todd WF. Prevalence of mixed infections in the diabetic pedal wound: a retrospective review of 112 infections. 1995 William J. Stickel bronze award. J Am Podiatr Med Assoc $1995 ; 85: 533-7$.
15. Calhoun JH, Cantrell J, Cobos J, et al. Treatment of diabetic foot infections: Wagner classification, therapy, and outcome. Foot Ankle 1988; 9:101-6.

16. Edelson GW, Armstrong DG, Lavery LA, Caicco G. The acutely infected diabetic foot is not adequately evaluated in an inpatient setting. Arch Intern Med 1996; 156:2373-8.

17. American Diabetes Association. Consensus development conference on diabetic foot wound care: 7-8 April 1999, Boston, Massachusetts. Diabetes Care 1999; 22:1354-60.

18. Frykberg RG, Armstrong DG, Giurini J, et al. Diabetic foot disorders: a clinical practice guideline. American College of Foot and Ankle Surgeons. J Foot Ankle Surg 2000;39:S1-60.

19. Pinzur MS, Slovenkai MP, Trepman E. Guidelines for diabetic foot care. The Diabetes Committee of the American Orthopaedic Foot and Ankle Society. Foot Ankle Int 1999; 20:695-702.

20. Lutter LD. Sooner beats the cost of later [editorial]. Foot Ankle Int 1995:387.

21. Armstrong DG. Is diabetic foot care efficacious or cost effective? Ostomy Wound Manage 2001; 47:28-32.

22. Piwernetz K, Home PD, Snorgaard O, Antsiferov M, Staehr-Johansen $\mathrm{K}$, Krans M. Monitoring the targets of the St. Vincent Declaration and the implementation of quality management in diabetes care: the DIABCARE initiative. The DIABCARE Monitoring Group of the St. Vincent Declaration Steering Committee. Diabet Med 1993; 10:371-7.

23. International Working Group on the Diabetic Foot. International consensus on the diabetic foot [CD-ROM]. Brussels: International Diabetes Foundation, May 2003.

24. Kish MA. Guide to development of practice guidelines. Clin Infect Dis 2001; 32:851-4.

25. Caputo GM, Cavanagh PR, Ulbrecht JS, Gibbons GW, Karchmer AW. Assessment and management of foot disease in patients with diabetes. N Engl J Med 1994;331:854-60.

26. Frykberg RG. Diabetic foot ulcers: current concepts. J Foot Ankle Surg 1998; 37:440-6.

27. Schubert S, Heesemann J. Infections in diabetes mellitus [in German]. Immun Infekt 1995; 23:200-4.

28. Gin H. Infection and diabetes [in French]. Rev Med Interne 1993; 14:32-8.

29. Joshi N, Caputo G, Weitekamp M, Karchmer A. Infections in patients with diabetes mellitus. N Engl J Med 1999;341:1906-12.

30. Geerlings SE, Hoepelman AIM. Immune dysfunction in patients with diabetes mellitus (DM). FEMS Immunology and Medical Microbiology 1999;26:259-65.

31. Lipsky BA, Pecoraro RE, Wheat LJ. The diabetic foot: soft tissue and bone infection. Infect Dis Clin North Am 1990; 4:409-32.

32. Grayson ML. Diabetic foot infections: antimicrobial therapy. Infect Dis Clin North Am 1995; 9:143-61.

33. Joseph WS, Axler DA. Microbiology and antimicrobial therapy of diabetic foot infections. Clin Podiatr Med Surg 1990; 7:467-81.

34. Goldstein EJ, Citron DM, Nesbit CA. Diabetic foot infections: bacteriology and activity of 10 oral antimicrobial agents against bacteria isolated from consecutive cases. Diabetes Care 1996; 19:638-41.

35. El-Tahawy AT. Bacteriology of diabetic foot. Saudi Med J 2000;21: $344-7$.

36. Urbancic-Rovan V, Gubina M. Bacteria in superficial diabetic foot ulcers. Diabet Med 2000; 17:814-5.

37. Sims D, Keating SE, DeVincentis AF. Bacteriology of diabetic foot ulcers. J Foot Surg 1984; 23:149-51.

38. Jones EW, Edwards R, Finch R, Jeffcoate WJ. A microbiological study of diabetic foot lesions. Diabet Med 1985;2:213-5.

39. Gerding DN. Foot infections in diabetic patients: the role of anaerobes. Clin Infect Dis 1995; 20(Suppl 2):S283-8.

40. Pathare NA, Bal A, Talvalkar GV, Antani DU. Diabetic foot infections: a study of microorganisms associated with the different Wagner grades. Indian J Pathol Microbiol 1998; 41:437-41.

41. Sapico FL, Witte JL, Canawati HN, Montgomerie JZ, Bessman AN. The infected foot of the diabetic patient: quantitative microbiology 
and analysis of clinical features. Rev Infect Dis 1984;6(Suppl 1): S171-6.

42. Wheat LJ, Allen SD, Henry M, et al. Diabetic foot infections: bacteriologic analysis. Arch Intern Med 1986; 146:1935-40.

43. Hunt JA. Foot infections in diabetes are rarely due to a single microorganism. Diabet Med 1992; 9:749-52.

44. Hartemann-Heurtier A, Robert J, Jacqueminet S, et al. Diabetic foot ulcer and multidrug-resistant organisms: risk factors and impact. Diabet Med 2004;21:710-5.

45. Eady EA, Cove JH. Staphylococcal resistance revisited: communityacquired methicillin-resistant Staphylococcus aureus-an emerging problem for the management of skin and soft tissue infections. Curr Opin Infect Dis 2003; 16:103-24.

46. Wagner A, Reike H, Angelkort B. Highly resistant pathogens in patients with diabetic foot syndrome with special reference to methicillin-resistant Staphylococcus aureus infections [in German]. Dtsch Med Wochenschr 2001; 126:1353-6.

47. Dang C, Prasad Y, Bouton A, Jude EB. Methicillin-resistant Staphylococcus aureus in the diabetic foot clinic: a worsening problem. Diabet Med 2003; 20:159-61.

48. Tentolouris N, Jude EB, Smirnof I, Knowles EA, Boulton AJ. Methicillin-resistant Staphylococcus aureus: an increasing problem in a diabetic foot clinic. Diabet Med 1999; 16:767-71.

49. Centers for Disease Control and Prevention. Vancomycin-resistant Staphylococcus aureus-Pennsylvania, 2002. MMWR Morb Mortal Wkly Rep 2002; 51:902.

50. Bessman AN, Geiger PJ, Canawati H. Prevalence of Corynebacteria in diabetic foot infections. Diabetes Care 1992; 15:1531-3.

51. Ge Y, MacDonald D, Hait H, Lipsky B, Zasloff M, Holroyd K. Microbiological profile of infected diabetic foot ulcers. Diabet Med 2002; 19:1032-4.

52. Sapico FL, Canawati HN, Witte JL, Montgomerie JZ, Wagner FW Jr., Bessman AN. Quantitative aerobic and anaerobic bacteriology of infected diabetic feet. J Clin Microbiol 1980; 12:413-20.

53. Axler DA. Microbiology of diabetic foot infections. J Foot Surg $1987 ; 26: S 3-6$.

54. Bowler PG, Duerden BI, Armstrong DG. Wound microbiology and associated approaches to wound management. Clin Microbiol Rev 2001; 14:244-69.

55. Sharp CS, Bessmen AN, Wagner FW Jr., Garland D, Reece E. Microbiology of superficial and deep tissues in infected diabetic gangrene. Surg Gynecol Obstet 1979; 149:217-9.

56. Bessman AN, Sapico FL, Tabatabai M, Montgomerie JZ. Persistence of polymicrobial abscesses in the poorly controlled diabetic host. Diabetes 1986; 35:448-53.

57. Borrero E, Rossini M Jr. Bacteriology of 100 consecutive diabetic foot infections and in vitro susceptibility to ampicillin/sulbactam versus cefoxitin. Angiology 1992; 43:357-61.

58. Viswanathan V, Jasmine JJ, Snehalatha C, Ramachandran A. Prevalence of pathogens in diabetic foot infection in South Indian type 2 diabetic patients. J Assoc Physicians India 2002; 50:1013-6.

59. American Diabetes Association. Peripheral arterial disease in people with diabetes. Diabetes Care 2003;26:3333-41.

60. Boyko EJ, Ahroni JH, Davignon D, Stensel V, Prigeon RL, Smith DG. Diagnostic utility of the history and physical examination for peripheral vascular disease among patients with diabetes mellitus. J Clin Epidemiol 1997; 50:659-68.

61. Apelqvist J, Larsson J, Agardh CD. The importance of peripheral pulses, peripheral oedema, and local pain for the outcome of diabetic foot ulcers. Diabet Med 1990; 7:590-4.

62. McGee SR, Boyko EJ. Physical examination and chronic lower-extremity ischemia: a critical review. Arch Intern Med 1998; 158: 1357-64.

63. Faglia E, Favales F, Quarantiello A, et al. Angiographic evaluation of peripheral arterial occlusive disease and its role as a prognostic determinant for major amputation in diabetic subjects with foot ulcers. Diabetes Care 1998;21:625-30.
64. Apelqvist J, Castenfors J, Larsson J, Stenstrom A, Agardh CD. Prognostic value of systolic ankle and toe blood pressure levels in outcome of diabetic foot ulcer. Diabetes Care 1989;12:373-8.

65. Emanuele MA, Buchanan BJ, Abraira C. Elevated leg systolic pressures and arterial calcification on diabetic occlusive vascular disease. Diabetes Care 1981; 4:289-92.

66. Windsor T. Influence of arterial disease on the systolic blood pressure gradients of the extremity. Am J Med Sci 1950;220:117-26.

67. Carter SA. Clinical measurement of systolic pressures in limbs with arterial occlusive disease. JAMA 1969; 207:1869-74.

68. LoGerfo FW, Coffman JD. Current concepts: vascular and microvascular disease of the foot in diabetes: implication for foot care. $\mathrm{N}$ Engl J Med 1984; 311:1615-9.

69. LoGerfo FW, Gibbons GW. Ischemia in the diabetic foot: modern concepts and management. Clinical Diabetes July/Aug 1989:72-5.

70. Boyko EJ, Ahroni JH, Stensel VL, Smith DG, Davignon DR, Pecoraro RE. Predictors of transcutaneous oxygen tension in the lower limbs of diabetic subjects. Diabet Med 1996; 13:549-54.

71. Kalani M, Brismar K, Fagrell B, Ostergren J, Jorneskog G. Transcutaneous oxygen tension and toe blood pressure as predictors of outcome of diabetic foot ulcers. Diabetes Care 1999;22:147-51.

72. Matsen FA 3rd, Wyss CR, Pedegana LR, et al. Transcutaneous oxygen tension measurement in peripheral vascular disease. Surg Gynecol Obstet 1980; 150:525-8.

73. Christensen KS, Klark M. Transcutaneous oxygen measurement in peripheral occlusive disease: an indicator of wound healing in leg amputation. J Bone Joint Surg 1986; 68:423-6.

74. Wyss CR, Robertson C, Love SJ, Harrington RM, Matsen FA 3rd. Relationship between transcutaneous oxygen tension, ankle blood pressure, and clinical outcome of vascular surgery in diabetic and nondiabetic patients. Surgery 1987; 101:56-62.

75. Sheffield PJ. Measuring tissue oxygen tension: a review. Undersea Hyperb Med 1988; 25:179-88.

76. Gaylarde PM, Fonseca VA, Llewellyn G, Sarkany I, Thomas PK, Dandona P. Transcutaneous oxygen tension in legs and feet of diabetic patients. Diabetes 1988; 37:714-6.

77. Sosenko JM, Kato M, Soto R, Build DE. Comparison of quantitative sensory-threshold measures for their association with foot ulceration in diabetic patients. Diabetes Care 1990; 13:1057-61.

78. Armstrong DG. The 10-g monofilament: the diagnostic divining rod for the diabetic foot? Diabetes Care 2000; 23:887.

79. Armstrong DG, Nguyen HC. Improvement in healing with aggressive edema reduction after debridement of foot infection in persons with diabetes. Arch Surg 2000; 135:1405-9.

80. Jones V. Debridement of diabetic foot lesions. The Diabetic Foot $1998 ; 1: 88-94$

81. Rauwerda JA. Foot debridement: anatomic knowledge is mandatory. Diabetes Metab Res Rev 2000; 16(Suppl 1):S23-6.

82. Smith J, Thow J. Is debridement effective for diabetic foot ulcers? A systematic review: 1. The Diabetic Foot 2001;1:10-4.

83. Grayson ML, Gibbons GW, Balogh K, Levin E, Karchmer AW. Probing to bone in infected pedal ulcers: a clinical sign of underlying osteomyelitis in diabetic patients. JAMA 1995;273:721-3.

84. Lipsky BA, Pecoraro RE, Larson SA, Hanley ME, Ahroni JH. Outpatient management of uncomplicated lower-extremity infections in diabetic patients. Arch Intern Med 1990; 150:790-7.

85. Pellizzer G, Strazzabosco M, Presi S, et al. Deep tissue biopsy vs. superficial swab culture monitoring in the microbiological assessment of limb-threatening diabetic foot infection. Diabet Med 2001; 18 : $822-7$.

86. Johnson S, Lebahn F, Peterson LR, Gerding DN. Use of an anaerobic collection and transport swab device to recover anaerobic bacteria from infected foot ulcers in diabetics. Clin Infect Dis 1995;20(Suppl 2):S289-90.

87. Lee PC, Turnidge J, McDonald PJ. Fine-needle aspiration biopsy in diagnosis of soft tissue infections. J Clin Microbiol 1985;22:80-3.

88. Enderle MD, Coerper S, Schweizer HP, et al. Correlation of imaging 
techniques to histopathology in patients with diabetic foot syndrome and clinical suspicion of chronic osteomyelitis: the role of high-resolution ultrasound. Diabetes Care 1999;22:294-9.

89. Williamson BR, Teates CD, Phillips CD, Croft BY. Computed tomography as a diagnostic aid in diabetic and other problem feet. Clin Imaging 1989; 13:159-63.

90. Morrison WB, Ledermann HP, Schweitzer ME. MR imaging of inflammatory conditions of the ankle and foot. Magn Reson Imaging Clin N Am 2001; 9:615-37, xi-xii.

91. Boutin RD, Brossmann J, Sartoris DJ, Reilly D, Resnick D. Update on imaging of orthopedic infections. Orthop Clin North Am 1998; 29:41-66.

92. Ledermann HP, Morrison WB, Schweitzer ME. MR image analysis of pedal osteomyelitis: distribution, patterns of spread, and frequency of associated ulceration and septic arthritis. Radiology 2002;223: $747-55$.

93. Ledermann HP, Morrison WB, Schweitzer ME. Pedal abscesses in patients suspected of having pedal osteomyelitis: analysis with MR imaging. Radiology 2002; 224:649-55.

94. Becker W. Imaging osteomyelitis and the diabetic foot. Q J Nucl Med 1999; 43:9-20.

95. Greenspan A, Stadalnik RC. A musculoskeletal radiologist's view of nuclear medicine. Semin Nucl Med 1997;27:372-85.

96. Palestro CJ, Torres MA. Radionuclide imaging in orthopedic infections. Semin Nucl Med 1997; 27:334-45.

97. Unal SN, Birinci H, Baktiroglu S, Cantez S. Comparison of Tc-99m methylene diphosphonate, Tc-99m human immune globulin, and Tc99m-labeled white blood cell scintigraphy in the diabetic foot. Clin Nucl Med 2001; 26:1016-21.

98. Wagner FW Jr. The diabetic foot. Orthopedics 1987; 10:163-72.

99. Oyibo SO, Jude EB, Tarawneh I, Nguyen HC, Harkless LB, Boulton AJ. A comparison of two diabetic foot ulcer classification systems: the Wagner and the University of Texas wound classification systems. Diabetes Care 2001; 24:84-8.

100. Pecoraro RE. Diabetic skin ulcer classification for clinical investigations. Clinical Materials 1991; 8:257-62.

101. Pecoraro RE, Reiber GE. Classification of wounds in diabetic amputees. Wounds 1990;2:65-73.

102. Lavery LA, Armstrong DG, Harkless LB. Classification of diabetic foot wounds. J Foot Ankle Surg 1996; 35:528-31.

103. Levin ME. Classification of diabetic foot wounds [editorial]. Diabetes Care 1998; 21:681.

104. Apelqvist J, Castenfors J, Larrson J, Stenstrom A, Agardh CD. Wound classification is more important than site of ulceration in the outcome of diaabetic foot ulcers. Diabet Med 1989; 6:526-30.

105. Jeffcoate WJ, Macfarlane RM, Fletcher EM. The description and classification of diabetic foot lesions. Diabet Med 1993; 10:676-9.

106. Macfarlane R, Jeffcoate W. Classification of diabetic foot ulcers: the S(AD) SAD system. The Diabetic Foot 1999;2:123-31.

107. Armstrong DG, Lavery LA, Harkless LB. Validation of a diabetic wound classification system: the contribution of depth, infection, and ischemia to risk of amputation. Diabetes Care 1998;21:855-9.

108. Foster A, Edmonds ME. Simple staging system: a tool for diagnosis and management. The Diabetic Foot 2000;3:56-62.

109. Trengove NJ, Stacey MC, McGechie DF, Mata S. Qualitative bacteriology and leg ulcer healing. J Wound Care 1996; 5:277-80.

110. Kingsley A. The wound infection continuum and its application to clinical practice. Ostomy Wound Manage 2003; 49:1-7.

111. O’Meara SM, Cullum NA, Majid M, Sheldon TA. Systematic review of antimicrobial agents used for chronic wounds. Br J Surg 2001; 88 $4-21$.

112. Robson MC, Mannari RJ, Smith PD, Payne WG. Maintenance of wound bacterial balance. Am J Surg 1999; 178:399-402.

113. Bowler PG. The $10^{5}$ bacterial growth guideline: reassessing its clinical relevance in wound healing. Ostomy Wound Manage 2003; 49:44-53.

114. Edmonds M, Foster A. The use of antibiotics in the diabetic foot Am J Surg 2004; 187:25S-28S.
115. Chantelau E, Tanudjaja T, Altenhofer F, Ersanli Z, Lacigova S, Metzger C. Antibiotic treatment for uncomplicated neuropathic forefoot ulcers in diabetes: a controlled trial. Diabet Med 1996; 13:156-9.

116. Hirschl M, Hirschl AM. bacterial flora in mal perforant and antimicrobial treatment with ceftriaxone. Chemotherapy 1992;38:275-80.

117. Cutting K, Harding K. Criteria for identifying wound infection. J Wound Care 1994; 3:198-201.

118. Schultz GS, Sibbald RG, Falanga V, et al. Wound bed preparation: a systematic approach to wound management. Wound Repair Regen 2003; 11(Suppl 1):S1-28.

119. Lipsky BA. A current approach to diabetic foot infections. Curr Infect Dis Rep 1999; 1:253-60.

120. Mancini L, Ruotolo V. Infection of the diabetic foot. Rays 1997; 22: 544-9.

121. Lipsky BA, Itani K, Norden C. Treating foot infections in diabetic patients: a randomized, multicenter, open-label trial of linezolid versus ampicillin-sulbactam/amoxicillin-clavulanate. Clin Infect Dis 2004; 38:17-24.

122. Leichter SB, Allweiss P, Harley J, et al. Clinical characteristics of diabetic patients with serious pedal infections. Metabolism 1988; 37: $22-4$.

123. Chang BB, Darling RC 3rd, Paty PS, Lloyd WE, Shah DM, Leather RP. Expeditious management of ischemic invasive foot infections. Cardiovasc Surg 1996; 4:792-5.

124. Rubinstein A, Pierce CE Jr., Bloomgarden Z. Rapid healing of diabetic foot ulcers with continuous subcutaneous insulin infusion. Am J Med $1983 ; 75: 161-5$.

125. Asfar SK, al-Arouj M, al-Nakhi A, Baraka A, Juma T, Johny M. Foot infections in diabetics: the antibiotic choice. Can J Surg 1993; 36: $170-2$.

126. West NJ. Systemic antimicrobial treatment of foot infections in diabetic patients. Am J Health Syst Pharm 1995;52:1199-207; quiz, 1239-40.

127. Cunha BA. Antibiotic selection for diabetic foot infections: a review. J Foot Ankle Surg 2000;39:253-7.

128. Krikava $\mathrm{K}$, Pospisil $\mathrm{M}$. The diabetic foot syndrome-antibiotic therapy [in Czech]. Rozhl Chir 1999; 78:295-8.

129. Lipsky BA. Evidence-based antibiotic therapy of diabetic foot infections. FEMS Immunol Med Microbiol 1999; 26:267-76.

130. Lipsky BA, McDonald D, Litka P. Treatment of infected diabetic foot ulcers: topical MSI-78 vs. oral ofloxacin. Diabetologia 1997; 40:482.

131. Raymakers JT, Schaper NC, van der Heyden JJ, Tordior JH, Kitslaar PJ. Penetration of ceftazidime into bone from severely ischaemic limbs. J Antimicrob Chemother 1998; 42:543-5.

132. Seabrook GR, Edmiston CE, Schmitt DD, Krepel C, Bandyk DF, Towne JB. Comparison of serum and tissue antibiotic levels in diabetes-related foot infections. Surgery 1991; 110:671-7.

133. Duckworth C, Fisher JF, Carter SA, et al. Tissue penetration of clindamycin in diabetic foot infections. J Antimicrob Chemother 1993; 31:581-4.

134. Legat FJ, Maier A, Dittrich P, et al. Penetration of fosfomycin into inflammatory lesions in patients with cellulitis or diabetic foot syndrome. Antimicrob Agents Chemother 2003; 47:371-4.

135. Muller M, Brunner M, Hollenstein U, et al. Penetration of ciprofloxacin into the interstitial space of inflamed foot lesions in non-insulin-dependent diabetes mellitus patients. Antimicrob Agents Chemother 1999; 43:2056-8.

136. Kuck EM, Bouter KP, Hoekstra JB, Conemans JM, Diepersloot RJ. Tissue concentrations after a single-dose, orally administered ofloxacin in patients with diabetic foot infections. Foot Ankle Int 1998; 19:38-40.

137. Mueller-Buehl U, Diehm C, Gutzler F, Adam D. Tissue concentrations of ofloxacin in necrotic foot lesions of diabetic and non-diabetic patients with peripheral arterial occlusive disease. Vasa 1991;20:17-21.

138. Raymakers JT, Houben AJ, van der Heyden JJ, Tordoir JH, Kitslaar PJ, Schaper NC. The effect of diabetes and severe ischaemia on the 
penetration of ceftazidime into tissues of the limb. Diabet Med 2001; 18:229-34.

139. Fierer J, Daniel D, Davis C. The fetid foot: lower-extremity infections in patients with diabetes mellitus. Rev Infect Dis 1979; 1:210-7.

140. Hughes CE, Johnson CC, Bamberger DM, et al. Treatment and longterm follow-up of foot infections in patients with diabetes or ischemia: a randomized, prospective, double-blind comparison of cefoxitin and ceftizoxime. Clin Ther 1987; 10(Suppl A):36-49.

141. LeFrock JL, Blais F, Schell RF, et al. Cefoxitin in the treatment of diabetic patients with lower extremity infections. Infect Surg 1983: 361-70.

142. Erstad BL, McIntyre KE. Prospective, randomized comparison of ampicillin/sulbactam and cefoxitin for diabetic foot infections. Vascular Surgery 1997; 31:419-26.

143. File TM Jr., Tan JS. Amdinocillin plus cefoxitin versus cefoxitin alone in therapy of mixed soft tissue infections (including diabetic foot infections). Am J Med 1983; 75:100-5.

144. Anania WC, Chinkes SL, Rosen RC, Turner PR, Helfand RE. A selective clinical trial of ceftizoxime. J Am Podiatr Med Assoc 1987; 77:648-52.

145. Lobmann R, Ambrosch A, Seewald M, et al. Antibiotic therapy for diabetic foot infections: comparison of cephalosporins with chinolones. Diabetes Nutr Metab 2004; 17:156-62.

146. Lipsky BA, Baker PD, Landon GC, Fernau R. Antibiotic therapy for diabetic foot infections: comparison of two parenteral-to-oral regimens. Clin Infect Dis 1997;24:643-8.

147. Grayson ML, Gibbons GW, Habershaw GM, et al. Use of ampicillin/ sulbactam versus imipenem/cilastatin in the treatment of limb-threatening foot infections in diabetic patients. Clin Infect Dis 1994; 18 : 683-93.

148. Akova M, Ozcebe O, Gullu I, et al. Efficacy of sulbactam-ampicillin for the treatment of severe diabetic foot infections. J Chemother 1996; 8:284-9.

149. Gerards V, Schiewe U, Gerards HH, Machka K, Hobel W, Meister W. Amoxicillin/clavulanic acid in therapy of bacterial infections of the diabetic foot: results of an observational study [in German]. MMW Fortschr Med 2000; 142:187-94.

150. Graham DR, Talan DA, Nichols RL, et al. Once-daily, high-dose levofloxacin versus ticarcillin-clavulanate alone or followed by amoxicillin-clavulanate for complicated skin and skin-structure infections: a randomized, open-label trial. Clin Infect Dis 2002; 35:381-9.

151. File TM Jr., Tan JS. Ticarcillin-clavulanate therapy for bacterial skin and soft tissue infections. Rev Infect Dis 1991; 13(Suppl 9):S733-6.

152. Zeillemaker AM, Veldkamp KE, van Kraaij MG, Hoekstra JB, Hoynck van Papendrecht AA, Diepersloot RJ. Piperacillin/tazobactam therapy for diabetic foot infection. Foot Ankle Int 1998; 19:169-72.

153. Marvaso A, Esposito S, Noviello S, et al. Outpatient Parenteral Antibiotic Therapy (OPAT) of diabetic foot infections with piperacillin/ tazobactam [in Italian]. Infez Med 2002; 10:230-5.

154. Siami FS, LaFleur BJ, Siami GA. Clinafloxacin versus piperacillin/ tazobactam in the treatment of severe skin and soft-tissue infections in adults at a Veterans Affairs medical center. Clin Ther 2002;24: 59-72.

155. Peterson LR, Lissack LM, Canter K, Fasching CE, Clabots C, Gerding DN. Therapy of lower extremity infections with ciprofloxacin in patients with diabetes mellitus, peripheral vascular disease, or both. Am J Med 1989; 86:801-8.

156. Beam TR Jr., Gutierrez I, Powell S, Hewitt R, Hocko M, Brackett M. Prospective study of the efficacy and safety of oral and intravenous ciprofloxacin in the treatment of diabetic foot infections. Rev Infect Dis 1989; 11(Suppl 5):S163.

157. Sesin GP, Paszko A, O’Keefe E. Oral clindamycin and ciprofloxacin therapy for diabetic foot infections. Pharmacotherapy 1990; 10:154-6.

158. Daniel R, Group TS. Once-daily oral trovafloxacin in the treatment of diabetic foot infections: results of an open-label, non-comparative, multicentre trial. Drugs 1999; 58:291-2.

159. Calandra GB, Raupp W, Brown KR. Imipenem/cilastatin treatment of lower extremity skin and soft tissue infections in diabetics. Scand J Infect Dis Suppl 1987; 52:15-9.

160. Bouter KP, Visseren FLJ, van Loenhour RMM, Bartelink AKM, Erkelens DW, Diepersloot RJA. Treatment of diabetic foot infection: an open randomised comparison of imipenem/cilastatin and piperacillin/ clindamyin combination therapy. Int J Antimicrob Agents 1996; 7: 143-7.

161. Gesser R, McCarroll K, Woods G. Efficacy of ertapenem for treatment of diabetic lower extremity infections: results of a comparative trial versus pipericillin-tazobactam [abstract 321]. In: Program and abstracts of the 41st Annual Meeting of the Infectious Diseases Society of America (San Diego). Alexandria, VA: Infectious Diseases Society of America, 2003:88.

162. Torres A, Ramirez-Ronda CH. Aztreonam in the treatment of soft tissue infections including diabetic foot infections. Bol Asoc Med P R 1985; 77:191-4.

163. Lipsky BA. Daptomycin for treating diabetic ulcer infections [abstract B-115]. In: Program and abstracts of the Annual Scientific Meeting of the American College of Foot \& Ankle Surgery (San Diego). Chicago: American College of Foot \& Ankle Surgery, 2004.

164. Steffen C, O'Rourke S. Surgical management of diabetic foot complications: the Far North Queensland profile. Aust N Z J Surg 1998;68: 258-60.

165. Giurini JM, Rosenblum BI. The role of foot surgery in patients with diabetes. Clin Podiatr Med Surg 1995; 12:119-27.

166. Bridges RM Jr., Deitch EA. Diabetic foot infections: pathophysiology and treatment. Surg Clin North Am 1994; 74:537-55.

167. Gill LH. Foot surgery in the patient with diabetes. J South Orthop Assoc 1994; 3:261-7.

168. Chaytor ER. Surgical treatment of the diabetic foot. Diabetes Metab Res Rev 2000; 16(Suppl 1):S66-9.

169. Armstrong DG, Frykberg RG. Classifying diabetic foot surgery: toward a rational definition. Diabet Med 2003; 20:329-31.

170. Scher KS, Steele FJ. The septic foot in patients with diabetes. Surgery 1988; 104:661-6.

171. Pinzur MS, Sage R, Abraham M, Osterman H. Limb salvage in infected lower extremity gangrene. Foot Ankle 1988; 8:212-5.

172. Tan JS, Friedman NM, Hazelton-Miller C, Flanagan JP, File TM Jr. Can aggressive treatment of diabetic foot infections reduce the need for above-ankle amputation? Clin Infect Dis 1996; 23:286-91.

173. Ha Van G, Siney H, Danan JP, Sachon C, Grimaldi A. Treatment of osteomyelitis in the diabetic foot: contribution of conservative surgery. Diabetes Care 1996; 19:1257-60.

174. Piaggesi A, Schipani E, Campi F, et al. Conservative surgical approach versus non-surgical management for diabetic neuropathic foot ulcers: a randomized trial. Diabet Med 1998; 15:412-7.

175. Bose K. A surgical approach for the infected diabetic foot. Int Orthop $1979 ; 3: 177-81$

176. Brodsky JW, Schneidler C. Diabetic foot infections. Orthop Clin North Am 1991;22:473-89.

177. Connolly JE, Wrobel JS, Anderson RF. Primary closure of infected diabetic foot wounds: a report of closed instillation in 30 cases. J Am Podiatr Med Assoc 2000; 90:175-82.

178. Pinzur MS. Amputation level selection in the diabetic foot. Clin Orthop 1993:68-70.

179. Pinzur MS, Pinto MA, Schon LC, Smith DG. Controversies in amputation surgery. Instr Course Lect 2003; 52:445-51.

180. Durham JR, McCoy DM, Sawchuk AP, et al. Open transmetatarsal amputation in the treatment of severe foot infections. Am J Surg 1989; 158:127-30.

181. Benton GS, Kerstein MD. Cost effectiveness of early digit amputation in the patient with diabetes. Surg Gynecol Obstet 1985; 161:523-4.

182. Field CK, Kerstein MD. Cost-benefit analysis of lower-extremity amputation: ethical considerations. Wounds 1993; 5:10-3.

183. Van Damme H, Rorive M, Martens De Noorthout BM, Quaniers J, Scheen A, Limet R. Amputations in diabetic patients: a plea for footsparing surgery. Acta Chir Belg 2001; 101:123-9. 
184. Khammash MR, Obeidat KA. Prevalence of ischemia in diabetic foot infection. World J Surg 2003; 27:797-9.

185. Lepantalo M, Biancari F, Tukiainen E. Never amputate without consultation of a vascular surgeon. Diabetes Metab Res Rev 2000; 16(Suppl 1):S27-32.

186. Gibbons GW. Lower extremity bypass in patients with diabetic foot ulcers. Surg Clin North Am 2003; 83:659-69.

187. Holstein PE, Sorensen S. Limb salvage experience in a multidisciplinary diabetic foot unit. Diabetes Care 1999; 22(Suppl 2):B97-103.

188. Estes JM, Pomposelli FB Jr. Lower extremity arterial reconstruction in patients with diabetes mellitus. Diabet Med 1996;13(Suppl 1): S43-7.

189. Akbari CM, Pomposelli FB Jr., Gibbons GW, et al. Lower extremity revascularization in diabetes: late observations. Arch Surg 2000; 135 : 452-6.

190. Taylor LM Jr., Porter JM. The clinical course of diabetics who require emergent foot surgery because of infection or ischemia. J Vasc Surg 1987; 6:454-9.

191. Steed DL, Donohoe D, Webster MW, Lindsley L. Effect of extensive debridement and treatment on the healing of diabetic foot ulcers. Diabetic Ulcer Study Group. J Am Coll Surg 1996; 183:61-4.

192. Smith J, Thow J. Is debridement effective for diabetic foot ulcers? A systematic review: 2. The Diabetic Foot 2001;4:77-80.

193. Lewis R, Whiting P, ter Riet G, O'Meara S, Galanville J. A rapid systematic review of the clinical effectiveness and cost effectiveness of debriding agents in treating surgical wounds healing by secondary intention: NHS HTA Programme, the National Institute of Clinical Excellence, NHS Centre for Reviews and Dissemination University of York, 2000:1-8.

194. Armstrong DG, Lavery LA, Vazquez JR, Nixon BP, Boulton AJ. How and why to surgically debride neuropathic diabetic foot wounds. J Am Podiatr Med Assoc 2002; 92:402-4.

195. Singhal A, Reis ED, Kerstein MD. Options for nonsurgical debridement of necrotic wounds. Adv Skin Wound Care 2001; 14:96-100.

196. O’Meara SO, Cullum N, Majid M, Sheldon T. Systematic reviews of wound care management: (3) antimicrobial agents for chronic wounds; (4) diabetic foot ulceration. Health Technol Assess 2000; 4 : $1-237$.

197. Nwomeh BC, Yager DR, Cohen IK. Physiology of the chronic wound. Clin Plast Surg 1998; 25:341-56.

198. Eaglstein WH, Falanga V. Chronic wounds. Surg Clin North Am 1997; 77:689-700.

199. Hogge J, Krasner D, Nguyen H, Harkless LB, Armstrong DG. The potential benefits of advanced therapeutic modalities in the treatment of diabetic foot wounds. J Am Podiatr Med Assoc 2000; 90:57-65.

200. Armstrong DG, Nguyen HC, Lavery LA, van Schie CH, Boulton AJ, Harkless LB. Off-loading the diabetic foot wound: a randomized clinical trial. Diabetes Care 2001;24:1019-22.

201. Armstrong DG, Lavery LA. Evidence-based options for off-loading diabetic wounds. Clin Podiatr Med Surg 1998; 15:95-104.

202. Boulton AJ. Pressure and the diabetic foot: clinical science and offloading techniques. Am J Surg 2004; 187:17S-24S.

203. Espensen EH, Nixon BP, Lavery LA, Armstrong DG. Use of subatmospheric (VAC) therapy to improve bioengineered tissue grafting in diabetic foot wounds. J Am Podiatr Med Assoc 2002; 92:395-7.

204. Joseph E, Hamori CA, Bergman S, Roaf E, Swann NF, Anastasi GW. A prospective, randomized trial of vacuum-assisted closure versus standard therapy of chronic non-healing wounds. Wounds 2000; 12 : 60-7.

205. McCallon SK, Knight CA, Valiulus JP, Cunningham MW, McCulloch JM, Farinas LP. Vacuum-assisted closure versus saline-moistened gauze in the healing of postoperative diabetic foot wounds. Ostomy Wound Manage 2000; 46:28-32, 34.

206. Armstrong DG, Lavery LA, Abu-Rumman P, et al. Outcomes of subatmospheric pressure dressing therapy on wounds of the diabetic foot. Ostomy Wound Manage 2002; 48:64-8.

207. Nagai MK, Embil JM. Becaplermin: recombinant platelet derived growth factor, a new treatment for healing diabetic foot ulcers. Expert Opin Biol Ther 2002; 2:211-8.

208. Embil JM, Papp K, Sibbald G, et al. Recombinant human platelet-derived growth factor-BB (becaplermin) for healing chronic lower extremity diabetic ulcers: an open-label clinical evaluation of efficacy. Wound Repair Regen 2000; 8:162-8.

209. Knighton DR, Fiegel VD. Growth factors and comprehensive surgical care of diabetic wounds [review]. Curr Opin Gen Surg 1993:32-9.

210. Smiell JM. Clinical safety of becaplermin (rhPDGF-BB) gel. Becaplermin Studies Group. Am J Surg 1998; 176:68S-73S.

211. Steed DL. Growth factors in the treatment of diabetic foot ulcers. Wounds 1993; 5:80-3.

212. Robson MC, Mustoe TA, Hunt TK. The future of recombinant growth factors in wound healing. Am J Surg 1998; 176:80S-82S.

213. Williams RL, Armstrong DG. Wound healing: new modalities for a new millennium. Clin Podiatr Med Surg 1998; 15:117-28.

214. Edmonds M, Bates M, Doxford M, Gough A, Foster A. New treatments in ulcer healing and wound infection. Diabetes Metab Res Rev 2000; 16(Suppl 1):S51-4.

215. Browne AC, Vearncombe M, Sibbald RG. High bacterial load in asymptomatic diabetic patients with neurotrophic ulcers retards wound healing after application of Dermagraft. Ostomy Wound Manage 2001 ; 47:44-9.

216. Veves A, Falanga V, Armstrong DG, Sabolinski ML. Graftskin, a human skin equivalent, is effective in the management of noninfected neuropathic diabetic foot ulcers: a prospective randomized multicenter clinical trial. Diabetes Care 2001; 24:290-5.

217. Bowler PG. Wound pathophysiology, infection and therapeutic options. Ann Med 2002; 34:419-27.

218. Wright JB, Lam K, Hansen D, Burrell RE. Efficacy of topical silver against fungal burn wound pathogens. Am J Infect Control 1999; 27: 344-50.

219. Mayer DA, Tsapogas MJ. Povidone-iodine and wound healing: a critical review. Wounds 1993; 5:14-23.

220. Mumcuoglu KY. Clinical applications for maggots in wound care. Am J Clin Dermatol 2001;2:219-27.

221. Rayman A, Stansfield G, Woollard T, Mackie A, Rayman G. Use of larvae in the treatment of the diabetic necrotic foot. The Diabetic Foot 1998; 1:7-13.

222. Claxton MJ, Armstrong DG, Short B, Vazquez JR, Boulton AJ. 5 Questions_and answers-about maggot debridement therapy. Adv Skin Wound Care 2003; 16:99-102.

223. Peck KR, Son DW, Song JH, Kim S, Oh MD, Choe KW. Enhanced neutrophil functions by recombinant human granulocyte colonystimulating factor in diabetic patients with foot infections in vitro. J Korean Med Sci 2001; 16:39-44.

224. Gough A, Clapperton M, Rolando N, Foster AV, Philpott-Howard J, Edmonds ME. Randomised placebo-controlled trial of granulocyte colony-stimulating factor in diabetic foot infection. Lancet 1997;350: 855-9.

225. de Lalla F, Pelizzer G, Strazzabosco M, et al. Randomized prospective controlled trial of recombinant granulocyte colony-stimulating factor as adjunctive therapy for limb-threatening diabetic foot infection. Antimicrob Agents Chemother 2001; 45:1094-8.

226. Kastenbauer T, Hornlein B, Sokol G, Irsigler K. Evaluation of granulocyte colony-stimulating factor (Filgrastim) in infected diabetic foot ulcers. Diabetologia 2003; 46:27-30.

227. Viswanathan V, Mahesh U, Jayaraman M, Shina K, Ramachandram A. Beneficial role of granulocyte colony-stimulating factor in foot infection in diabetic patients. J Assoc Physicians India 2003; 51:90-1.

228. Lipsky BA, Berendt AR, Embil J, De Lalla F. Diagnosing and treating daibetic foot infections. Diabetes Metab Res Rev 2004;20(Suppl 1): S56-64.

229. Bakker DJ. Hyperbaric oxygen therapy and the diabetic foot. Diabetes Metab Res Rev 2000; 16(Suppl 1):S55-8.

230. Kalani M, Jorneskog G, Naderi N, Lind F, Brismar K. Hyperbaric 
oxygen (HBO) therapy in treatment of diabetic foot ulcers: long-term follow-up. J Diabetes Complications 2002; 16:153-8.

231. Wang C, Schwaitzberg S, Berliner E, Zarin DA, Lau J. Hyperbaric oxygen for treating wounds: a systematic review of the literature. Arch Surg 2003; 138:272-9; discussion 280.

232. Wunderlich RP, Peters EJ, Lavery LA. Systemic hyperbaric oxygen therapy: lower-extremity wound healing and the diabetic foot. Diabetes Care 2000; 23:1551-5.

233. Kranke P, Bennett M, Roeckl-Wiedmann I, Debus S. Hyperbaric oxygen therapy for chronic wounds. Cochrane Database Syst Rev 2004: CD004123.

234. Lee SS, Chen CY, Chan YS, Yen CY, Chao EK, Ueng SW. Hyperbaric oxygen in the treatment of diabetic foot infection. Changgeng Yi Xue Za Zhi 1997;20:17-22.

235. Armstrong DG, Lavery LA, Sariaya M, Ashry H. Leukocytosis is a poor indicator of acute osteomyelitis of the foot in diabetes mellitus. J Foot Ankle Surg 1996;35:280-3.

236. Kaleta JL, Fleischli JW, Reilly CH. The diagnosis of osteomyelitis in diabetes using erythrocyte sedimentation rate: a pilot study. J Am Podiatr Med Assoc 2001; 91:445-50.

237. Eneroth M, Larsson J, Apelqvist J. Deep foot infections in patients with diabetes and foot ulcer: an entity with different characteristics, treatments, and prognosis. J Diabetes Complications 1999; 13:254-63.

238. Upchurch GR Jr., Keagy BA, Johnson G Jr. An acute phase reaction in diabetic patients with foot ulcers. Cardiovasc Surg 1997; 5:32-6.

239. Jeffcoate WJ, Lipsky BA. Controversies in diagnosing and managing osteomyelitis of the foot in diabetes. Clin Infect Dis 2004;39(Suppl 2):S115-22.

240. Lipsky BA. Osteomyelitis of the foot in diabetic patients. Clin Infect Dis 1997; 25:1318-26.

241. Snyder RJ, Cohen MM, Sun C, Livingston J. Osteomyelitis in the diabetic patient: diagnosis and treatment. Part 1: overview, diagnosis, and microbiology. Ostomy Wound Manage 2001; 47:18-22, 25-30; quiz $31-2$.

242. Snyder RJ, Cohen MM, Sun C, Livingston J. Osteomyelitis in the diabetic patient: diagnosis and treatment. Part 2: medical, surgical, and alternative treatments. Ostomy Wound Manage 2001; 47:24-30, 32-41; quiz 42-3.

243. Embil JM. The management of diabetic foot osteomyelitis. The Diabetic Foot 2000; 3:76-84.

244. Eckman MH, Greenfield S, Mackey WC, et al. Foot infections in diabetic patients: decision and cost-effectiveness analyses. JAMA 1995; 273:712-20.

245. Newman LG, Waller J, Palestro CJ, et al. Unsuspected osteomyelitis in diabetic foot ulcers: diagnosis and monitoring by leukocyte scanning with indium in 111 oxyquinoline. JAMA 1991;266:1246-51.

246. Rajbhandari SM, Sutton M, Davies C, Tesfaye S, Ward JD. "Sausage toe": a reliable sign of underlying osteomyelitis. Diabet Med 2000; 17:74-7.

247. Shults DW, Hunter GC, McIntyre KE, Parent FN, Piotrowski JJ, Bernhard VM. Value of radiographs and bone scans in determining the need for therapy in diabetic patients with foot ulcers. Am J Surg 1989; 158:525-9; discussion 529-30.

248. Lipman BT, Collier BD, Carrera GF, et al. Detection of osteomyelitis in the neuropathic foot: nuclear medicine, MRI and conventional radiography. Clin Nucl Med 1998;23:77-82.

249. Bonham P. A critical review of the literature: part 1: diagnosing osteomyelitis in patients with diabetes and foot ulcers. J Wound Ostomy Continence Nurs 2001;28:73-88.

250. Bonham P. A critical review of the literature: part II: antibiotic treatment of osteomyelitis in patients with diabetes and foot ulcers. J Wound Ostomy Continence Nurs 2001;28:141-9.

251. Tan JS, File TM Jr. Diagnosis and treatment of diabetic foot infections. Baillieres Best Pract Res Clin Rheumatol 1999; 13:149-61.

252. Maugendre D, Poirier JY. Nuclear medicine in the diagnosis of diabetic foot osteomyelitis [in French]. Diabetes Metab 2001;27:396-400.
253. Rosenthall L. Radionuclide investigation of osteomyelitis. Curr Opin Radiol 1992; 4:62-9.

254. Newman LG. Imaging techniques in the diabetic foot. Clin Podiatr Med Surg 1995; 12:75-86.

255. Jay PR, Michelson JD, Mizel MS, Magid D, Le T. Efficacy of threephase bone scans in evaluating diabetic foot ulcers. Foot Ankle Int 1999; 20:347-55.

256. Levine SE, Neagle CE, Esterhai JL, Wright DG, Dalinka MK. Magnetic resonance imaging for the diagnosis of osteomyelitis in the diabetic patient with a foot ulcer. Foot Ankle Int 1994; 15:151-6.

257. Marcus CD, Ladam-Marcus VJ, Leone J, Malgrange D, Bonnet-Gausserand FM, Menanteau BP. MR imaging of osteomyelitis and neuropathic osteoarthropathy in the feet of diabetics. Radiographics 1996; 16:1337-48.

258. Ledermann HP, Schweitzer ME, Morrison WB. Nonenhancing tissue on MR imaging of pedal infection: characterization of necrotic tissue and associated limitations for diagnosis of osteomyelitis and abscess. AJR Am J Roentgenol 2002; 178:215-22.

259. Vesco L, Boulahdour H, Hamissa S, et al. The value of combined radionuclide and magnetic resonance imaging in the diagnosis and conservative management of minimal or localized osteomyelitis of the foot in diabetic patients. Metabolism 1999; 48:922-7.

260. Wrobel JS, Connolly JE. Making the diagnosis of osteomyelitis: the role of prevalence. J Am Podiatr Med Assoc 1998; 88:337-43.

261. Poirier JY, Garin E, Derrien C, et al. Diagnosis of osteomyelitis in the diabetic foot with a $99 \mathrm{mTc}-\mathrm{HMPAO}$ leucocyte scintigraphy combined with a $99 \mathrm{mTc}-\mathrm{MDP}$ bone scintigraphy. Diabetes Metab 2002; 28 : 485-90.

262. Rubello D, Casara D, Maran A, Avogaro A, Tiengo A, Muzzio PC. Role of anti-granulocyte $\mathrm{Fab}^{\prime}$ fragment antibody scintigraphy (LeukoScan) in evaluating bone infection: acquisition protocol, interpretation criteria and clinical results. Nucl Med Commun 2004; 25:39-47.

263. Palestro CJ, Caprioli R, Love C, et al. Rapid diagnosis of pedal osteomyelitis in diabetics with a technetium-99m-labeled monoclonal antigranulocyte antibody. J Foot Ankle Surg 2003; 42:2-8.

264. Harwood SJ, Valdivia S, Hung G-L, Quenzer RW. Use of sulesomab, a radiolabeled antibody fragment, to detect osteomyelitis in diabetic patients with foot ulcers by leukocintigraphy. Clin Infect Dis 1999; 28:1200-5.

265. Mader JT, Ortiz M, Calhoun JH. Update on the diagnosis and management of osteomyelitis. Clin Podiatr Med Surg 1996; 13:701-24.

266. Wheat J. Diagnostic strategies in osteomyelitis. Am J Med 1985; 78: 218-24.

267. Howard CB, Einhorn M, Dagan R, Yagupski P, Porat S. Fine-needle bone biopsy to diagnose osteomyelitis. J Bone Joint Surg Br 1994; 76:311-4.

268. Khatri G, Wagner DK, Sohnle PG. Effect of bone biopsy in guiding antimicrobial therapy for osteomyelitis complicating open wounds. Am J Med Sci 2001;321:367-71.

269. White LM, Schweitzer ME, Deely DM, Gannon F. Study of osteomyelitis: utility of combined histologic and microbiologic evaluation of percutaneous biopsy samples. Radiology 1995; 197:840-2.

270. Zuluaga AF, Galvis W, Jaimes F, Vesga O. Lack of microbiological concordance between bone and non-bone specimens in chronic osteomyelitis: an observational study. BMC Infect Dis 2002;2:8.

271. Venkatesan P, Lawn S, Macfarlane RM, Fletcher EM, Finch RG, Jeffcoate WJ. Conservative management of osteomyelitis in the feet of diabetic patients. Diabet Med 1997; 14:487-90.

272. Senneville E, Yazdanpanah Y, Cazaubiel M, et al. Rifampicin-ofloxacin oral regimen for the treatment of mild to moderate diabetic foot osteomyelitis. J Antimicrob Chemother 2001; 48:927-30.

273. Pittet D, Wyssa B, Herter-Clavel C, Kursteiner K, Vaucher J, Lew PD. Outcome of diabetic foot infections treated conservatively: a retrospective cohort study with long-term follow-up. Arch Intern Med 1999; 159:851-6.

274. Yadlapalli N, Vaishnar A, Sheehan P. Conservative management of 
diabetic foot ulcers complicated by osteomyelitis. Wounds 2002; 14 : $31-5$.

275. Nix DK, Cumbo TJ, Kuritzky P, Devito JM, Shentag JJ. Oral ciprofloxacin in the treatment of serious soft tissue and bone infection: efficacy, safety, and pharmacokinetics. Am J Med 1987; 82(Suppl 4A): $146-53$.

276. Bamberger DM, Daus GP, Gerding DN. Osteomyelitis in the feet of diabetic patients: long-term results, prognostic factors, and the role of antimicrobial and surgical therapy. Am J Med 1987; 83:653-60.

277. Roeder B, Van Gils CC, Maling S. Antibiotic beads in the treatment of diabetic pedal osteomyelitis. J Foot Ankle Surg 2000;39:124-30.

278. Wininger DA, Fass RJ. Antibiotic-imgregnated cement and beads for orthopedic infections. Antimicrob Agents Chemother 1996;40: 2675-9.

279. Yamashita Y, Uchida A, Yamakawa T, Shinto Y, Araki N, Kato K. Treatment of chronic osteomyelitis using calcium hydraxyapatite ceramic implants impregnated with antibiotic. Int Orthop 1998;22: $247-51$.

280. Jacobs AM, Siefert AM, Kirisits TJ, Protzel HR. Use of antibioticloaded bone cement in the management of common infections of the foot and ankle. Clin Podiatr Med Surg 1990; 7:523-44.

281. Fox HR, Karchmer AW. Management of diabetic foot infections, including the use of home intravenous antibiotic therapy. Clin Podiatr Med Surg 1996; 13:671-82.

282. Tice A, Hoaglund P, Shoultz DA. Outcomes of osteomyelitis among patients treated with outpatient parenteral antimicrobial therapy. Am J Med 2003; 114:723-8.
283. Diamantopoulos EJ, Haritos D, Yfandi G, et al. Management and outcome of severe diabetic foot infections. Exp Clin Endocrinol Diabetes 1998; 106:346-52.

284. Eneroth M, Apelqvist J, Stenstrom A. Clinical characteristics and outcome in 223 diabetic patients with deep foot infections. Foot Ankle Int 1997; 18:716-22.

285. Balsells M, Viade J, Millan M, et al. Prevalence of osteomyelitis in non-healing diabetic foot ulcers: usefulness of radiologic and scintigraphic findings. Diabetes Res Clin Pract 1997; 38:123-7.

286. Wong YS, Lee JC, Yu CS, Low BY. Results of minor foot amputations in diabetic mellitus. Singapore Med J 1996; 37:604-6.

287. Kaufman J, Breeding L, Rosenberg N. Anatomic location of acute diabetic foot infection: its influence on the outcome of treatment. Am Surg 1987; 53:109-12.

288. Perencevich EN, Kaye KS, Strausbaugh LJ, Fisman DN, Harris AD. Acceptable rates of treatment failure in osteomyelitis involving the diabetic foot: a survey of infectious diseases specialists. Infectious Diseases Society of America Emerging Infections Network. Clin Infect Dis 2004; 38:976-82.

289. Apelqvist J, Bakker K, van Houtum WH, Nabuurs-Franssen MH, Schaper NC. International consensus and practical guidelines on the management and the prevention of the diabetic foot. Diabetes Metab Res Rev 2000; 16(Suppl 1):S84-92.

290. Inlow S, Orsted H, Sibbald RG. Best practices for the prevention, diagnosis, and treatment of diabetic foot ulcers. Ostomy Wound Manage 2000; 46:55-68; quiz 70-1. 